\title{
Impact of Agricultural Investments on World Wheat Market under Climate Change: Effects of Agricultural Knowledge and Innovation System, and Development and Maintenance of Infrastructure
}

\author{
Tatsuji KOIZUMI* \\ Policy Research Institute of Japan's Ministry of Agriculture, Forestry and Fisheries (Chiyoda-ku, \\ Tokyo 100-0013, Japan)
}

\begin{abstract}
The role of agricultural investment growth in alleviating climate risks for wheat production systems and markets was examined using a partial equilibrium model, the Wheat Economy Climate Change (WECC) model, which covers the wheat markets of 10 countries and two regions. This study examines how future agricultural investments will affect the world wheat market. The volatility of international wheat prices at baseline is expected to increase in 2014-2016 and until 2040 because of climate change. However, a constant increase in agricultural investments in major producing countries will contribute to international wheat price stability. In particular, agricultural investments in Russia are crucial for stabilizing international wheat prices in mid-long term under future climate change conditions.
\end{abstract}

Discipline: Agricultural economics

Additional key words: partial equilibrium model, wheat price, price stability in mid-long term, Russia and Ukraine

\section{Introduction}

The increase in global mean surface temperatures in 2081-2100 relative to $1986-2005$ is estimated between $0.3^{\circ} \mathrm{C}$ and $4.8^{\circ} \mathrm{C}$, depending on representative concentration pathways (RCPs). Agricultural production will thus be affected by this climate change in different ways, including changes in yield and harvested area. Numerous studies exist on how future climate change could impact global agricultural production. For instance, Lobel (2007) examined the changes in diurnal temperature range and national cereal yield, and Furuya et al. (2015) developed yield-response functions for the world food model to evaluate climate change effects by incorporating a crop model into the yield-trend functions ${ }^{11}$. Moreover, Furuya and Koyama (2005) examined how climate change will impact world grain

${ }^{1}$ For further studies, please refer to Koizumi and Kanamaru (2016). markets, and Koizumi and Kanamaru (2016) examined how agricultural investments, based on FAO data, will impact rice price volatility under climate change. After remaining at historic lows for decades, food prices have significantly increased and become more volatile since 2007. Price volatility has a strong impact on food security in developing countries (Food and Agriculture Organization, FAO 2011). Moreover, the coefficient of variation $(\mathrm{CV})$ for international wheat prices was 0.1664 from 1985 to $1995,0.2425$ from 1996 to 2005, and 0.2645 from 2006 to $2015^{2}$; therefore, the volatility is increasing. FAO (2011) concluded that agricultural investments could reduce food price volatility through increased productivity and improved technical management of production risk, especially in the face of climate change. This report was based on policy implications for policy makers and did not conduct simulation analysis. Koizumi and Kanamaru

*Corresponding author: e-mail koizu@affrc.go.jp

Received 26 February 2018; accepted 18 July 2018. 
(2016) were the first to evaluate how future agricultural investments will impact the world rice market, especially the volatility of international rice prices, by factoring in future climate change. This study examines how agricultural investment will contribute to stabilizing world wheat market by factoring future climate change. This study utilizes Organisation of Economic CoOperation and Development (OECD)-based agricultural investment data on developed countries and FAO-based data on developing countries to conduct simulations for alleviating climate risks for wheat production systems and markets through a partial equilibrium model.

\section{Structure of the WECC model and data for regression}

The Wheat Economy Climate Change (WECC) model covers the wheat markets in 10 countries and two regions (EU28, China, India, USA, Russia, Ukraine, Canada, Australia, Argentina, Indonesia, Egypt, and the rest of the world). The model also covers Germany, France, and other EU production to aggregate EU wheat production. The base year range is 2014-2016 (3-year average for 2014-2016). Each country's market consists of production, consumption, exports, imports, and ending stock until 2040. The WECC model covers equations for projecting wheat yield and planted area affected by climate change (Fig. 1). This study applied an Error Correction Model in order to evaluate the long-run equilibrium relationships among economic variables.

The wheat yield equation for developed countries depends on annual flowering season averages of temperature, precipitation, amount of solar radiation, and lagging investments ${ }^{3}$. The wheat-planted area

${ }^{3}$ Constant term and time trend are estimated; however they are
not applied for projections. Instead of statistically estimated
constant term and time trend, this study applied a coefficient of
calibration to improve reality for the model projection activity.
The coefficient of calibration obtained to correct each market
activity of the first projection year (2017) is equivalent to the
updated estimation data (2017) published by USDA-FAS (2017).

Future Climate Change

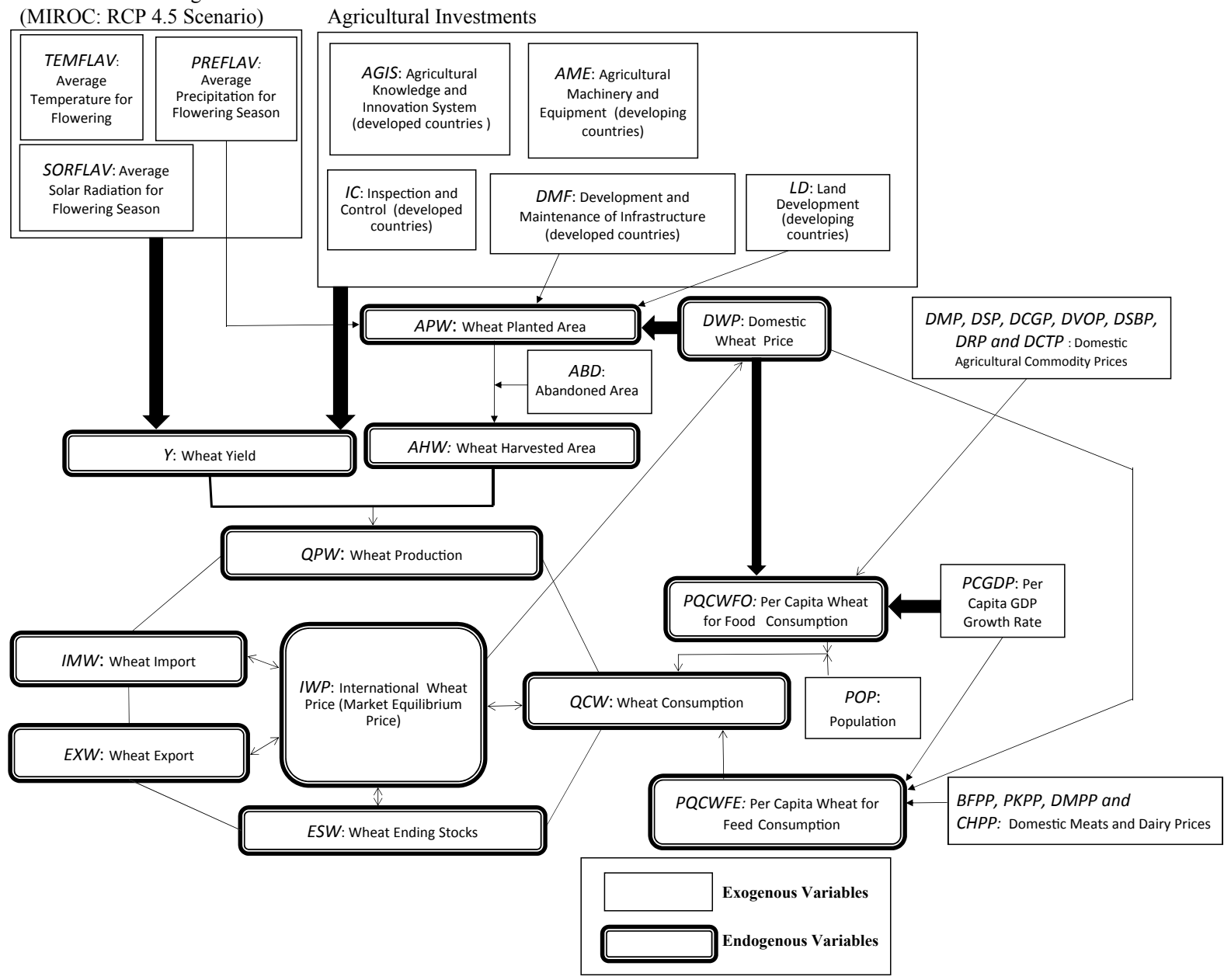

Fig. 1. Structure of the WECC model 
equation depends on the domestic prices of wheat, competitive commodity prices, precipitation, and lagging investments. Changing rate from current to previous year of climate variables and price variables effect on wheat yield and wheat-planted area. The lagged changing rate of agricultural investment variables effect on wheat yield and wheat-planted area. They mean that agricultural investments can impact wheat yield and wheat-planted area with a lag, different from climate and price variables. The WECC model is developed as a new model to cover agricultural investment variables derived from both OECD and FAO. The model also covers different climate variables from a rice model (RECC model $)^{4}$. Consequently, the model approach is different from Koizumi and Kanamaru (2016), and the model has originality to differ from the previous model approaches.

The wheat-harvested area is derived from the difference between the planted and abandoned areas. Further, wheat production is calculated by multiplying the harvested area and wheat yield as follows:

$$
\begin{aligned}
& \ln \left(Y_{t, c} / Y_{t-1, c}\right)=\mathrm{a} 1 \ln \left(T E M F L A V_{t, c} / T E M F L A V_{t-1, c}\right)+ \\
& \mathrm{a} 2 \ln \left(P R E F L A V_{t, c} / P R E F L A V_{t-1, c}\right)+\mathrm{a} 3 \\
& \ln \left(S O R F L A V_{t, c} / S O R F L A V_{t-1, c}\right)+\mathrm{a} 4 \ln \\
& \left(A G I S_{t-1, c} / A G I S_{t-2, c}\right)+\mathrm{a} 5 \ln \left(D M F_{t-1, c} / D M F_{t-2, c}\right) \\
& +\mathrm{a} 6 \ln \left(I C_{t-1, c} / I C_{t-2, c}\right)+\mathrm{a} 7 \ln \left(L D_{t-1, c} / L D_{t-2, c}\right)+\mathrm{a} 8 \ln \\
& \quad\left(A M E_{t-1, c} / A M E_{t-2, c}\right)^{5}
\end{aligned}
$$

$$
\begin{aligned}
& \ln \left(A P W_{t, \mathrm{c}} / A P W_{t-1, c}\right)=\mathrm{a} 9 \ln \left(D W P_{t, c} D W P_{t-1, c}\right)+\mathrm{a} 10 \ln
\end{aligned}
$$

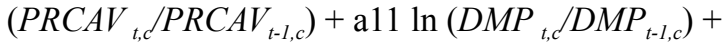

$$
\begin{aligned}
& \text { a12 } \ln \left(D S P_{t, c} / S P_{t-1, c}\right)+\text { a } 13 \ln \left(D C G P_{t, c} / D C G P_{t-1, c}\right) \\
& \text { + a14 } \ln \left(D V O P_{t, c} / D V O P_{t-1, c}\right)+\mathrm{a} 15 \ln \\
& \left(D S B P_{t, c} / D S B P_{t-1, c}\right)+\mathrm{a} 16 \ln \left(D R P_{t, c} / D R P_{t-1, c}\right)+\mathrm{a} 17 \\
& \ln \left(D M F_{t-1, c} / D M F_{t-2, c}\right)+\mathrm{a} 18 \ln \left(D C T P_{t, c} / D C T P_{t-1, c}\right) \\
& \text { + a19 } \ln \left(L D_{t-1, c} / L D_{t-2, c}\right)^{6} \\
& A H W_{t, c}=A P W_{t, c}-A B D_{t, c}{ }^{7} \\
& Q P W_{t, c}=A H W_{t, c} * Y_{t, c}^{8}
\end{aligned}
$$

The per capita wheat consumption for food depends on income, domestic prices of wheat and rice, and time trend. The per capita wheat consumption for feed depends on income, domestic wheat price, beef, pork, and cheese prices $^{9}$.

$$
\begin{aligned}
& \ln \left(P Q C W F O_{t, c} / P Q C W F O_{t-l, c}\right)=\mathrm{a} 20 \ln \\
& \quad\left(P C G D P_{t, c}\left(P C G D P_{t-l, c}\right)+\mathrm{a} 21 \ln \left(D W P_{t, c} / D W P_{t-l, c}\right)\right. \\
& \quad+\mathrm{a} 22 \ln \left(D R P_{t, c} / D R P_{t-l, c}\right)^{10} \\
& Q C W F O_{t, c}=P Q C W F O_{t, c} * P O P_{t, c} 11 \\
& \ln \left(Q C W F E_{t, c} / Q C W F E_{t-l, c}\right)=\mathrm{a} 23 \ln \left(G D P_{t, c} / G D P_{t-l, c}\right) \\
& \quad+\mathrm{a} 24 \ln \left(D W P_{t, c} / D W P_{t-l, c}\right)+\mathrm{a} 25 \ln \\
& \quad\left(B F P P_{t, c} / B F P P_{t-l, c}\right)+\mathrm{a} 26 \ln \left(P K P P_{t, c} / P K P P_{t-l, c}\right) \\
& \quad+\mathrm{a} 27 \ln \left(C H P P_{t, c} / C H P P_{t-l, c}\right) \\
& Q C W_{t, c}=Q C W F O_{t, c}+Q C W F E_{t, c}^{12}
\end{aligned}
$$

For net wheat exporting countries, wheat imports are based on domestic wheat price. Wheat exports are calculated by the exportable domestic market balance

\footnotetext{
${ }^{7} A H W$ is the harvested area, and $A B D$ is the abandoned area. The abandoned area is an exogenous variable and will be utilized for simulation in future studies.

8 This equation is a feed demand element function for livestock production; however, the impact of income elasticity is bigger than that of price elasticity. Consequently, income elasticity is incorporated into this equation.

9 This equation is a feed demand element function for livestock production; however, the impact of income elasticity is bigger than that of price elasticity. Consequently, income elasticity is incorporated into this equation.

${ }^{10} P Q C W F O$ is the per capita wheat consumption for food, $P C G D P$ is the per capita GDP (constant price), and a20-a22 are parameters. Tables 3-1, 3-2, and 3-3 list these estimated parameters.

${ }^{11} Q C W F O$ is the wheat consumption for food, and $P O P$ is the population.

${ }^{12} Q C W F E$ is the wheat consumption for feed, GDP is the GDP (constant price), $B F P P$ is the domestic beef price, $P K P P$ is the domestic pork price, $C H P P$ is the domestic cheese price, and a23-a27 are parameters. Tables 4-1 and 4-2 list these estimated parameters.

${ }^{13} Q C W$ is wheat consumption.
} 
deficit remaining after the domestic market has been satisfied.

$$
\begin{aligned}
& \ln \left(I M W_{t, c} / I M W_{t-1, c}\right)=\mathrm{a} 28 \ln \left(D W P_{t, c} / D W P_{t-1, c}\right)^{14} \\
& E X W_{t, c}=Q P W_{t, c}-Q C W_{t, c}+I M W_{t, c}- \\
& \quad\left(E S W_{t, c}-E S W_{t-1, c}\right)^{15}
\end{aligned}
$$

For net wheat importing countries, wheat exports depend on international wheat price. Wheat imports are calculated by the exportable domestic market balance deficit remaining after the domestic market has been satisfied as follows:

$$
\begin{aligned}
& \ln \left(E X W_{t, c} / E X W_{t-1, c}\right)=\mathrm{a} 29 \ln \left(I W P_{t} / I W P_{t-1}\right)^{16} \\
& I M W_{t, c}=Q C W_{t, c}-Q P W_{t, c}+E X W_{t, c}+ \\
& \quad\left(E S W_{t, c}-E S W_{t-l, c}\right)
\end{aligned}
$$

Wheat ending stocks depend on domestic wheat price. The domestic wheat price is based on the international wheat price as follows:

$$
\begin{aligned}
& \ln \left(E S W_{t, c} / E S W_{t-1, c}\right)=\mathrm{a} 30 \ln \left(D W P_{t, c} / D W P_{t-1, c}\right)^{17} \\
& \ln \left(D W P_{t, c} / D W P_{t-1, c}\right)=\mathrm{a} 31 \ln \left(I W P_{t, c} / I W P_{t-1, c}\right)^{18}
\end{aligned}
$$

The model determines the production, consumption, imports, and ending stocks for each simulation year. The wheat market clearing price is obtained from the following equilibrium conditions using the Gauss-Seidel algorithm: Wheat, No. 1 Hard Red Winter, ordinary protein, Kansas City, which refers to the international wheat market clearing price ${ }^{19}$.

$$
\Sigma \quad I M W_{t, c}=\Sigma \quad E X W_{t, c}
$$

Historical temperatures, precipitation, and solar radiation data are derived from CRU TS 3.2 (University

\footnotetext{
${ }^{14} I M W$ is wheat import, and a28 is a parameter. Tables A5-1 and 5-2 lists the estimated parameters.

${ }^{15} E X W$ denotes wheat exports, and $E S W$ is the ending stocks of wheat.

${ }^{16}$ a29 is a parameter. $I W P$ is the international wheat price.

Table A6 lists the estimated parameters.

17 a30 is a parameter. Tables A7-1, A7-2, and A7-3 list the estimated parameters.

${ }^{18}$ a31 is a parameter. A8-1 and A8-2 list the estimated parameters.

${ }_{19}$ Wheat is categorized into four types (hard wheat, soft wheat, intermediate quality wheat, and durum) for its application. Among them, hard wheat, especially for Wheat, No. 1 Hard Red Winter, ordinary protein, Kansas City, is most typically utilized for world wheat trade.

${ }^{20}$ West Australia for Australia, Saskatchewan State for Canada, Kansas State for USA, Punjab for India, North China
}

of East Anglia). For larger countries, the values for the grids that correspond to major wheat-producing areas are averaged $^{20}$. For the other countries, the values for all grids that cover the entire territory are spatially averaged. The historical yield, planted area, harvested area, production, per capita consumption, imports, exports, and ending stock data for wheat $^{21}$ are derived from Production, Supply and Distribution (PS\&D) (USDA-FAS 2017). This study defines wheat producer price as the domestic wheat price, derived from FAOSTAT (FAO). These data are used for regression in the time-series analysis.

\section{Baseline assumptions and scenarios}

The baseline outlook adopts a set of assumptions for the general economy, agricultural policies, and technological changes without any policy shock during the outlook period. The climate variables (temperatures, precipitation, and amount of solar radiation) for both the baseline outlook and policy scenario come from the climate change projections of the Model for Interdisciplinary Research on Climate (MIROC), a global climate model under the RCP 4.5 scenario. Spatially averaged climate variables for each country are computed similarly to the historical climate data used for regression. The flowering seasons for model covered countries differ as Table 1. The standard deviations for temperature, precipitation, and solar radiation during the flowering season in most analyzed countries are projected to increase in 2017-2040 compared to 1980-2009 (Tables 2, 3, and 4). The exogenous variables for per capita GDP growth rate, population, international commodity prices, and livestock production are listed in Tables A9-1 and A9-2 $2^{22}$. This study assumes that current agricultural and trade policies will continue, and abandoned areas will become zero in all countries throughout the outlook

Region for China, and Southern Russia (Black Sea Coastal Area) for Russia.

${ }^{21}$ The results of unit root tests (ADF test) confirmed that the time-series data of dependent variables and explanatory variables used in this study are stationary series.

${ }^{22}$ The population data for all countries were obtained from the 2017 Revision (medium variant) of World Population Prospects, United Nations (2017). The per capita real GDP was also treated as an exogenous variable, and GDP growth rate assumptions were based on World Economic Outlook 2017 (IMF 2017). These GDP growth rates are available up to 2022. This study assumes that the average per capita GDP growth rate from 2017 to 2022 in each country will continue to be the same in 20232040. Competing commodity prices and domestic livestock production are derived from OECD-FAO Agricultural Outlook 2017-2026 (OECD-FAO 2017). 
Table 1. Planning, Harvesting and flowering seasons for model covered countries

\begin{tabular}{llll}
\hline \hline Countries & Planting & Harvesting & Flowering \\
\hline Germany (EU) & October & August & June to July \\
France (EU) & October to November & July to August & May to June \\
Poland (EU) & September to October & July to August & May to June \\
China & October to November & May to June & April to May \\
India & October to November & April to May & February to March \\
USA & September to October & June to August & May to June \\
Russia & August to September & July to August & June \\
Ukraine & August to September & July to August & June \\
Canada & May to June & June to October & June to July \\
Australia & April to June & October to December & August to September \\
Argentina & May to July & November to January & September to October \\
Egypt & September to October & April to August & March to April \\
Pakistan (The rest of the world) & October to December & March to April & February to March \\
\hline
\end{tabular}

Table 2. Standard deviations for the average temperature $\left({ }^{\circ} \mathrm{C}\right)$ during the flowering season

\begin{tabular}{lccccc}
\hline \hline & $1980-1989$ & $1990-1999$ & $2000-2009$ & $2017-2026$ (Projection) & 2027-2040 (Projection) \\
\hline German (EU) & 1.1193 & 0.6820 & 1.1283 & 0.4553 & 0.8672 \\
France (EU) & 1.0648 & 0.7556 & 0.4560 & 0.6994 & 0.7473 \\
Poland (EU) & 0.9657 & 0.9118 & 1.0141 & 1.0808 & 0.9868 \\
China & 0.3145 & 0.8586 & 0.4877 & 0.7367 & 2.2790 \\
India & 0.8275 & 0.7211 & 0.8361 & 0.9056 & 1.1104 \\
USA & 1.0382 & 1.0768 & 0.5719 & 0.7718 & 1.1870 \\
Russia & 1.4340 & 1.2104 & 0.5957 & 1.0770 & 0.8453 \\
Ukraine & 1.0610 & 1.3199 & 0.9755 & 1.3926 & 1.1375 \\
Canada & 1.0491 & 1.0723 & 1.1027 & 1.4069 & 0.7741 \\
Australia & 0.7620 & 0.6974 & 0.5486 & 0.6989 & 0.6632 \\
Argentina & 0.4872 & 0.2416 & 0.6635 & 0.9171 & 0.7326 \\
Egypt & 1.0264 & 0.8066 & 0.8038 & 0.9015 & 1.1727 \\
Pakistan (The rest of the world) & 1.0943 & 0.6800 & 0.9708 & 0.8186 & 1.4280 \\
\hline
\end{tabular}

Table 3. Standard deviations for the average precipitation $(\mathrm{mm})$ during the flowering season

\begin{tabular}{lrrrrr}
\hline \hline & $1980-1989$ & $1990-1999$ & $2000-2009$ & $2017-2026$ (Projection) & 2027-2040 (Projection) \\
\hline German (EU) & 19.8870 & 10.6641 & 16.0834 & 10.8339 & 16.4337 \\
France (EU) & 18.1433 & 14.7955 & 17.4974 & 10.3621 & 7.2470 \\
Poland (EU) & 7.5331 & 9.9083 & 17.2434 & 18.0844 & 19.7753 \\
China & 12.0804 & 13.6838 & 19.5637 & 10.4693 & 13.9853 \\
India & 5.1607 & 6.9931 & 7.2761 & 8.7790 & 11.9685 \\
USA & 16.4108 & 17.2637 & 18.3846 & 15.1192 & 23.5297 \\
Russia & 9.0648 & 10.6106 & 9.4302 & 13.4176 & 12.6190 \\
Ukraine & 13.5169 & 18.0339 & 7.2924 & 26.9470 & 28.4940 \\
Canada & 10.9840 & 17.0611 & 9.7627 & 11.5968 & 12.8768 \\
Australia & 7.5456 & 9.9710 & 7.6615 & 9.5303 & 6.3625 \\
Argentina & 21.6510 & 12.5778 & 25.1198 & 21.3412 & 20.1479 \\
Egypt & 0.1322 & 0.4566 & 0.2514 & 3.1710 & 2.2699 \\
Pakistan (The rest of the world) & 9.0684 & 5.0736 & 13.2703 & 8.1918 & 11.9762 \\
\hline
\end{tabular}


period.

This study applies the Agricultural knowledge and innovation system ${ }^{23}$, development and maintenance of infrastructure ${ }^{24}$, and inspection and control ${ }^{25}$ for Australia, Canada, the USA, the EU, Russia, and Ukraine. These time-series data are derived from $O E C D$ General Service Support Estimates (GSSE) (OECD) ${ }^{26}$. Land development ${ }^{27}$ and agricultural machinery and equipment are applied for other countries (India, China, Egypt, Argentina, and Pakistan (the rest of the world)). Both OECD and FAOSTAT agricultural investment data can be used not only for wheat but also for other crops. However, this study covers major wheat-producing countries. Therefore, it assumes that these agricultural investments will be mainly used for wheat production, and the current growth rate of agricultural knowledge and innovation system, development and maintenance of infrastructure, and inspection and control from 2006 to 2015 for Australia, Canada, the USA, and the EU will continue during the outlook period $(2017-2040)^{28}$

\footnotetext{
23 The agricultural knowledge and innovation system covers agricultural knowledge generation and agricultural knowledge transfer.

24 The development and maintenance of infrastructure covers hydrological infrastructures, storage, marketing, other physical and institutional infrastructure, and farm restructuring.

25 Inspection and control covers agricultural product safety and inspection, pest and disease inspection and control, and input control.

${ }^{26}$ GSSE is summed up by all types of agricultural indicators by OECD and not assumed to have inflation problems for targeted countries (Interviewed from OECD Trade and Agriculture Directorate, 2018.4).

${ }^{27}$ Land development is the result of actions leading to major improvements in land quantity, quality, or productivity, or which prevent its deterioration. These time-series data are derived from FAOSTAT (FAO). These data are summed up by
}

(Table 5). We also assume that the current growth rate of agricultural knowledge and innovation system, and development and maintenance of infrastructure from 2006 to 2011 in Russia and Ukraine will continue during the outlook period ${ }^{29}$. This study also assumes that the current growth rate of land development and agricultural machinery and equipment from 1990 to 2007 in other countries (India, China, Egypt, Argentina, and Pakistan (the rest of the world)) will continue during the outlook period (Table 6$)^{30}$.

This study applied alternative scenarios to the baseline outlook. This study examines the impact of agricultural investment on world wheat markets. Consequently, this study applied the growth rate of agricultural investments will be zero for major producing countries as scenarios. The growth rates of agricultural knowledge and innovation system, and development and maintenance of infrastructure in Australia under scenario 1, that in the USA under scenario 2, that in Russia under scenario 3, and that in Ukraine under

the same methods of GSSE and not assumed to have inflation problems.

${ }^{28}$ The growth rates of investments in development and maintenance of infrastructure in the USA from 2006 to 2015 were $10.9 \%$ on average, which seems too high. Instead, we apply the growth rates from 2012 to 2015 for USA (0.7\%) to the baseline outlook period.

${ }^{29}$ The growth rates of investments in development and maintenance of infrastructure in Russia from 2006 to 2011 were $18.5 \%$, which seems too high. Instead, we apply the growth rates from 2005 to 2007 for Russia (2.7\%) to the projection period.

30 The growth rates of agricultural machinery \& equipment in India from 1990 to 2007 were $6.6 \%$, which seems too high. As a result, this study applies the growth rate from 2003 to 2004 for India $(2.4 \%)$ to the projection period.

Table 4. Standard deviations for the average amount of solar radiation (MJ/day) during the flowering season

\begin{tabular}{lccccc}
\hline \hline & $1980-1989$ & $1990-1999$ & $2000-2009$ & $2017-2026$ (Projection) & 2027-2040 (Projection) \\
\hline German (EU) & 1.5030 & 0.7520 & 1.4370 & 0.7720 & 0.8888 \\
France (EU) & 1.0637 & 0.8383 & 1.0883 & 0.9437 & 0.7118 \\
Poland (EU) & 1.0032 & 1.2344 & 0.6923 & 1.1887 & 1.0050 \\
China & 0.5721 & 0.9583 & 1.0214 & 0.6597 & 1.4808 \\
India & 0.1395 & 0.2106 & 0.3365 & 0.6575 & 0.7047 \\
USA & 0.3528 & 0.3018 & 0.3456 & 0.4609 & 0.7369 \\
Russia & 0.1295 & 0.4355 & 0.6760 & 0.4183 & 0.3737 \\
Ukraine & 0.5686 & 1.0536 & 1.0219 & 0.8330 & 0.7486 \\
Canada & 0.3624 & 0.5306 & 0.3086 & 0.3342 & 0.5653 \\
Australia & 0.2140 & 0.2179 & 0.1528 & 0.3191 & 0.3578 \\
Argentina & 0.3624 & 0.3466 & 1.0090 & 0.7890 & 0.4236 \\
Egypt & 0.1657 & 0.5272 & 0.1542 & 0.6438 & 0.5546 \\
Pakistan (The rest of the world) & 0.1248 & 0.1807 & 0.3592 & 0.5879 & 0.7519 \\
\hline
\end{tabular}


scenario 4 are hypothesized to be zero from 2017 to 2040. This study focuses on the OECD-based agricultural investment impact on world wheat market and wheat price stability ${ }^{31}$, which means that it does not target

31 Among model covered countries, this study assumes that the development and maintenance of infrastructure in Canada will decrease during the projection period. Therefore, Canada is excluded from the scenario targeting countries. The agricultural investment data for EU member countries do not appear in the scenario simulation for FAO-based land development and agricultural machinery, and equipment in China, India, and Argentina.

OECD General Service Support Estimates data. This study focuses on the country-based agricultural investment impact on the world wheat market and wheat price volatility. Therefore, it excludes the EU from the scenario simulation countries.

Table 5. Growth rate (\%) of agricultural investments in developed countries, Russia and Ukraine

\begin{tabular}{|c|c|c|c|c|c|c|}
\hline Country & "Agricultural investments & 1986-1995 & 1996-2005 & 2006-2015 & $2006-2010$ & $2012-2015$ \\
\hline \multirow[t]{2}{*}{ Australia } & $\begin{array}{l}\text { Agricultural knowledge and } \\
\text { innovation system }\end{array}$ & 12.7 & 5.0 & 1.8 & 0.4 & 0.6 \\
\hline & $\begin{array}{l}\text { Development and } \\
\text { maintenance of infrastructure }\end{array}$ & - & 26.3 & 2.4 & -13.4 & 8.0 \\
\hline \multirow[t]{2}{*}{ Canada } & $\begin{array}{l}\text { Agricultural knowledge and } \\
\text { innovation system }\end{array}$ & 1.8 & 1.2 & 1.4 & 2.9 & 0.3 \\
\hline & $\begin{array}{l}\text { Development and } \\
\text { maintenance of infrastructure }\end{array}$ & -6.7 & 2.4 & -2.9 & -6.0 & 6.9 \\
\hline \multirow[t]{2}{*}{ USA } & $\begin{array}{l}\text { Agricultural knowledge and } \\
\text { innovation system }\end{array}$ & 3.7 & 2.5 & 2.6 & -0.3 & -0.5 \\
\hline & $\begin{array}{l}\text { Development and } \\
\text { maintenance of infrastructure }\end{array}$ & 9.0 & 48.5 & 10.9 & -7.8 & 0.7 \\
\hline \multirow[t]{4}{*}{ EU } & $\begin{array}{l}\text { Agricultural knowledge and } \\
\text { innovation system }\end{array}$ & 6.9 & 5.2 & 3.0 & 4.0 & 4.0 \\
\hline & Inspection and control & -0.8 & 14.4 & 1.6 & -4.4 & 2.0 \\
\hline & $\begin{array}{l}\text { Development and } \\
\text { maintenance of infrastructure }\end{array}$ & 4.5 & 6.0 & -0.3 & 2.8 & 0.5 \\
\hline & & 1986-1995 & $2005-2007$ & 2006-2011 & $2005-2007$ & \\
\hline \multirow[t]{2}{*}{ Russia } & $\begin{array}{l}\text { Agricultural knowledge and } \\
\text { innovation system }\end{array}$ & 34.2 & 2.3 & 16.0 & 2.3 & \\
\hline & $\begin{array}{l}\text { Development and } \\
\text { maintenance of infrastructure }\end{array}$ & 10.5 & 18.5 & 2.7 & 18.5 & \\
\hline \multirow[t]{2}{*}{ Ukraine } & $\begin{array}{l}\text { Agricultural knowledge and } \\
\text { innovation system }\end{array}$ & 25.2 & 16.3 & 2.3 & 6.9 & \\
\hline & $\begin{array}{l}\text { Development and } \\
\text { maintenance of infrastructure }\end{array}$ & 12.8 & 13.2 & 1.5 & 15.9 & \\
\hline
\end{tabular}

Table 6. Growth rate (\%) of agricultural investments in other countries

\begin{tabular}{|c|c|c|c|c|c|c|}
\hline Country & Agricultural investments & $1975-1985$ & $1985-1995$ & $1996-2007$ & $1990-2007$ & $2003-2004$ \\
\hline \multirow[t]{2}{*}{ India } & Land Development & 1.1 & 1.2 & 0.7 & 0.9 & -0.1 \\
\hline & Agricultural machinery \& equipment & 7.2 & 5.9 & 7.4 & 6.6 & 2.4 \\
\hline \multirow[t]{2}{*}{ China } & Land Development & 1.1 & 1.1 & 0.8 & 0.9 & 2.0 \\
\hline & Agricultural machinery \& equipment & 7.0 & -0.8 & 7.6 & 4.4 & 4.1 \\
\hline \multirow[t]{2}{*}{ Egypt } & Land Development & -1.2 & 2.7 & 0.6 & 1.7 & 0.1 \\
\hline & Agricultural machinery \& equipment & 6.1 & 3.9 & 1.1 & 2.7 & 5.9 \\
\hline \multirow[t]{2}{*}{ Argentina } & Land Development & 2.4 & 2.2 & 1.9 & 1.8 & 2.2 \\
\hline & Agricultural machinery \& equipment & 6.0 & 1.8 & -0.1 & 0.6 & -1.3 \\
\hline \multirow{2}{*}{$\begin{array}{l}\text { Pakistan } \\
\text { (The rest of the World) }\end{array}$} & Land Development & 1.2 & 0.8 & 0.7 & 1.0 & 1.9 \\
\hline & Agricultural machinery \& equipment & 13.6 & 5.4 & 0.6 & 1.4 & 0.3 \\
\hline
\end{tabular}




\section{Results}

Under the baseline assumptions, world wheat production is expected to increase at a rate of $1.3 \%$ per annum from 2014-2016 to 2040 (Table 7), and consumption is expected to increase at a rate of $1.4 \%$ per annum from 2014-2016 to 2040 (Table 8). World wheat exports and imports are expected to increase at a rate of $2.5 \%$ per annum during the same period (Table 8). World wheat ending stocks are expected to decrease at a rate of $0.1 \%$ per annum during the same period. The international wheat price is projected to increase from
190.0 USD/t in 2014-2016 to $208.9 \mathrm{USD} / \mathrm{t}$ in $2040^{32}$. The CV of international wheat price from 2014/2016 to 2040 is 0.3159 .

Outlooks were made using various agricultural investment scenarios in selected countries for comparison against the baseline outlook. These agricultural investments can be considered to be working as climate change adaptation measures. Under scenario 1, Australian wheat production is expected to decrease

\footnotetext{
${ }^{32}$ The projected price is constant price.
}

Table 7. World wheat yield, harvested area and production (baseline outlook)

\begin{tabular}{|c|c|c|c|c|c|c|c|c|c|}
\hline & \multicolumn{2}{|c|}{ Yield } & \multirow{2}{*}{$\begin{array}{c}\text { (MT/ha) } \\
\text { Growth rate }(\%) \\
(2014 / 16-2040)\end{array}$} & \multicolumn{2}{|c|}{ Harvested area } & \multirow{2}{*}{$\begin{array}{c}(1,000 \text { ha }) \\
\text { Growth rate }(\%) \\
(2014 / 16-2040)\end{array}$} & \multicolumn{2}{|c|}{ Production } & \multirow{2}{*}{$\begin{array}{c}(1,000 \mathrm{MT}) \\
\text { Growth rate }(\%) \\
(2014 / 16-2040)\end{array}$} \\
\hline & 2014-16 & $\begin{array}{c}2040 \\
\text { (Projection) }\end{array}$ & & 2014-16 & $\begin{array}{c}2040 \\
\text { (Projection) }\end{array}$ & & 2014-16 & $\begin{array}{c}2040 \\
\text { (Projection) }\end{array}$ & \\
\hline World & - & - & - & 160,386 & 226,203 & 1.4 & 739,981 & $1,009,417$ & 1.3 \\
\hline EU & - & - & - & 26,966 & 23,367 & -0.6 & 154,364 & 183,216 & 0.7 \\
\hline France (EU) & 6.8 & 8.8 & 1.1 & 5,436 & 4,710 & -0.6 & 36,987 & 41,682 & 0.5 \\
\hline Germany (EU) & 8.1 & 10.0 & 0.9 & 3,235 & 3,045 & -0.3 & 26,266 & 30,571 & 0.6 \\
\hline Other EU & 5.0 & 7.1 & 1.5 & 18,295 & 15,612 & -0.7 & 91,111 & 110,962 & 0.8 \\
\hline China & 5.3 & 6.5 & 0.8 & 24,133 & 18,837 & -1.0 & 128,416 & 121,732 & -0.2 \\
\hline India & 2.9 & 3.9 & 1.2 & 30,721 & 28,887 & -0.3 & 89,793 & 112,411 & 0.9 \\
\hline USA & 3.1 & 4.3 & 1.3 & 18,561 & 17,092 & -0.3 & 58,041 & 73,938 & 1.0 \\
\hline Russia & 2.5 & 4.9 & 2.8 & 25,406 & 29,921 & 0.7 & 64,218 & 145,175 & 1.0 \\
\hline Ukraina & 4.0 & 3.8 & -0.2 & 6,622 & 6,699 & 0.0 & 26,275 & 25,315 & 2.0 \\
\hline Canada & 3.2 & 2.6 & -0.8 & 9,312 & 15,425 & 2.1 & 29,571 & 40,565 & 1.3 \\
\hline Australia & 2.2 & 2.8 & 1.1 & 12,676 & 12,190 & -0.2 & 27,673 & 34,388 & 0.9 \\
\hline Argentina & 3.0 & 3.2 & 0.3 & 4,701 & 4,384 & -0.3 & 14,243 & 14,042 & 2.0 \\
\hline Indonesia & 0.0 & 0.0 & - & 0 & 0 & - & 0 & 0 & - \\
\hline Egypt & 6.3 & 5.5 & -0.6 & 1,290 & 1,640 & 1.0 & 8,167 & 9,073 & 0.4 \\
\hline
\end{tabular}

Table 8. World wheat consumption, exports and imports (baseline outlook)

\begin{tabular}{|c|c|c|c|c|c|c|c|c|c|}
\hline & \multicolumn{2}{|c|}{ Consumption } & \multirow{2}{*}{$\begin{array}{c}(1,000 \mathrm{MT}) \\
\text { Growth rate }(\%) \\
(2014 / 16-2040)\end{array}$} & \multicolumn{2}{|c|}{ Exports } & \multirow{2}{*}{$\begin{array}{c}(1,000 \mathrm{MT}) \\
\text { Growth rate }(\%) \\
(2014 / 16-2040) \\
\end{array}$} & \multicolumn{2}{|c|}{ Imports } & \multirow{2}{*}{$\begin{array}{c}(1,000 \mathrm{MT}) \\
\text { Growth rate }(\%) \\
(2014 / 16-2040) \\
\end{array}$} \\
\hline & 2014-16 & $\begin{array}{c}2040 \\
\text { (Projection) }\end{array}$ & & 2014-16 & $\begin{array}{c}2040 \\
\text { (Projection) }\end{array}$ & & $2014-16$ & $\begin{array}{c}2040 \\
\text { (Projection) }\end{array}$ & \\
\hline World & 715,017 & $1,011,141$ & 1.4 & 173,103 & 314,167 & 2.5 & 169,391 & 314,166 & 2.5 \\
\hline EU & 127,676 & 122,108 & -0.2 & 32,380 & 66,830 & 3.1 & 6,065 & 5,752 & -0.2 \\
\hline China & 115,667 & 195,179 & 2.2 & 777 & 765 & -0.1 & 3,401 & 74,470 & 13.7 \\
\hline India & 93,051 & 134,733 & 1.6 & 1,646 & 4,340 & 4.1 & 2,139 & 26,596 & 11.1 \\
\hline USA & 31,649 & 42,504 & 1.2 & 24,469 & 36,930 & 1.7 & 3,466 & 3,614 & 0.2 \\
\hline Russia & 37,500 & 35,333 & -0.2 & 25,381 & 110,075 & 6.3 & 550 & 330 & -2.1 \\
\hline Ukraina & 11,333 & 12,506 & 0.4 & 15,567 & 12,769 & -0.8 & 31 & 24 & -1.1 \\
\hline Canada & 9,041 & 13,410 & 1.7 & 22,183 & 28,879 & 1.1 & 491 & 543 & 0.4 \\
\hline Australia & 7,462 & 7,787 & 0.2 & 18,905 & 26,064 & 1.3 & 153 & 176 & 0.6 \\
\hline Argentina & 6,050 & 8,461 & 1.4 & 8,867 & 5,596 & -1.9 & 17 & 17 & 0.0 \\
\hline Indonesia & 8,655 & 14,091 & 2.1 & 286 & 363 & 1.0 & 9,198 & 14,473 & 1.9 \\
\hline Egypt & 19,333 & 26,754 & 1.4 & 466 & 966 & 3.1 & 11,575 & 18,658 & 2.0 \\
\hline
\end{tabular}


by $6.9 \%$ and exports by $8.7 \%$ compared to the baseline outlook average from 2017 to 2040 . Consequently, the international wheat price is expected to increase by $1.6 \%$ (Table 9). Under scenario 2, the US wheat production is expected to decrease by $5.3 \%$, and exports by $9.4 \%$ compared to the baseline outlook average from 2017 to 2040. Consequently, the international wheat price is expected to increase by $3.0 \%$ (Table 9). Under scenario 3 , Russian wheat production is expected to decrease by $16.0 \%$, and exports by $27.9 \%$ compared to the baseline outlook average from 2017 to 2040 . World wheat production and consumption are expected to decrease by $0.6 \%$, and world wheat exports and imports to decrease by $1.8 \%$. Consequently, the international wheat price is expected to increase by $11.0 \%$ (Table 9). In scenario 4 , Ukrainian wheat production is expected to decrease by $18.8 \%$, and exports by $31.5 \%$ compared to the baseline outlook average from 2017 to 2040 . World wheat production and consumption are expected to decrease by $0.2 \%$, and world wheat exports and imports to decrease by $0.7 \%$. Consequently, the international wheat price is expected to increase by $3.8 \%$ (Table 9 ).

The CVs of the international wheat prices from 2014-2016 to 2040 in all scenarios are higher than those in the baseline outlook (Table 10). As a result, the CV is calculated as 0.3223 during the simulation period (scenario 1), 0.3237 (scenario 2), 0.3278 (scenario 3), and 0.3267 (scenario 4), as shown in Table 10. The CV from scenario 3 is slightly higher than that from scenario 4. Consequently, the impact from scenario 3 on Russia is the most important for stabilizing the international wheat price among the scenario targeted countries.

\section{Conclusion}

This study conducted simulations on alleviating climate risks for wheat production systems and markets by utilizing a partial equilibrium model. It examined how future agricultural investments would impact the world wheat market, especially the stability of international

Table 9. Average changing rate (\%) between scenarios and baseline from 2017 to 2040

\begin{tabular}{|c|c|c|c|c|c|c|c|}
\hline & $\begin{array}{l}\text { Changing } \\
\text { rate between } \\
\text { Scenario } 1 \\
\text { and Baseline } \\
\text { projection from } \\
2017-2040\end{array}$ & a & $\begin{array}{l}\text { Changing } \\
\text { rate between } \\
\text { Scenario } 2 \\
\text { and Baseline } \\
\text { projection from } \\
2017-2040\end{array}$ & & $\begin{array}{l}\text { Changing } \\
\text { rate between } \\
\text { Scenario } 3 \\
\text { and Baseline } \\
\text { projection from } \\
2017-2040\end{array}$ & & $\begin{array}{l}\text { Changing } \\
\text { rate between } \\
\text { Scenario } 4 \\
\text { and Baseline } \\
\text { projection from } \\
2017-2040\end{array}$ \\
\hline Australia & & USA & & Russia & & Ukraine & \\
\hline Yield & -6.2 & Yield & -5.9 & Yield & -16.3 & Yield & -15.8 \\
\hline Harvested area & -0.8 & Harvested area & 0.6 & Harvested area & 0.4 & Harvested area & -3.9 \\
\hline Production & -6.9 & Production & -5.3 & Production & -16.0 & Production & -18.8 \\
\hline Export & -8.7 & Export & -9.4 & Export & -27.9 & Export & -31.5 \\
\hline Consumption & -0.4 & Consumption & -0.2 & Consumption & -1.0 & Consumption & -0.3 \\
\hline Import & -0.3 & Import & -0.7 & Import & -7.3 & Import & -3.6 \\
\hline World & & World & & World & & World & \\
\hline Production & -0.1 & Production & -0.2 & Production & -0.6 & Production & -0.2 \\
\hline Consumption & -0.1 & Consumption & -0.2 & Consumption & -0.6 & Consumption & -0.2 \\
\hline Export & -0.3 & Export & -0.6 & Export & -1.8 & Export & -0.7 \\
\hline Import & -0.3 & Import & -0.6 & Import & -1.8 & Import & -0.7 \\
\hline $\begin{array}{l}\text { International } \\
\text { wheat price }\end{array}$ & 1.6 & $\begin{array}{l}\text { International } \\
\text { wheat price }\end{array}$ & 3.0 & $\begin{array}{l}\text { International } \\
\text { wheat price }\end{array}$ & 11.0 & $\begin{array}{l}\text { International } \\
\text { wheat price }\end{array}$ & 3.8 \\
\hline
\end{tabular}

Table 10. Scenario impacts on international wheat price (2014/16-2040)

\begin{tabular}{llccc}
\hline \hline Scenario/Baseline & Country & Coefficient of variation $(\mathrm{CV})$ & Standard Deviation & Average \\
\hline Baseline & - & 0.3159 & 96.7592 & 306.2864 \\
Scenario 1 & Australia & 0.3223 & 100.4110 & 311.5611 \\
Scenario 2 & USA & 0.3237 & 102.2517 & 315.9130 \\
Scenario 3 & Russia & 0.3278 & 111.1265 & 339.0133 \\
Scenario 4 & Ukraine & 0.3267 & 104.0369 & 318.4654 \\
\hline
\end{tabular}


wheat price, by considering future climate change in midlong term. The simulation results suggest that agricultural investments in major wheat-producing countries will contribute to price stability in mid-long term, by considering climate change. Among scenarios, the changing rates of wheat production and export in scenario 3 (Russia) are higher than those in other scenarios. Russia is projected to become the world's largest wheat exporting country in the baseline outlook, and it means that Russian wheat production and export will the most crucial factor that can impact the world wheat market. As a result of this study, Russian agricultural investment is the biggest factor that can impact the world wheat market. In conclusion, agricultural investments in Russia play a crucial role in stabilizing international wheat prices in mid-long term, as wheat production becomes increasingly affected by climate change. This study applied specific assumptions to baseline and scenario outlooks, but could also apply other macro-assumptions and climate change projections to the baseline and scenario outlooks as a future direction of study. This model may have simultaneous determination bias in each elasticity, and examining and eliminating this bias are also the future direction of this study.

\section{Acknowledgements}

The author wishes to thank Dr. Motoki Nishimori, a staff member of the Institute for Agro-Environmental Sciences, National Agriculture and Food Research Organization, for providing the historical and forecast climate data.

\section{References}

Climate Research Unit (CRU) at the University of East Anglia, Climate Research Unit (CRU) Time-series datasets of variations in climate with variations in other phenomena, CRP.

Food and Agricultural Organization (FAO) FAOSTAT, FAO statistic databases. http://faostat.fao.org/.

Food and Agricultural Organization (FAO) (2011) The State of Food Security in the world. How does international policy volatility affect domestic economics and food security?

Furuya, J. \& Koyama, O. (2005) Impacts of Climate Change on World Agricultural Product Markets: Estimation of Macro Yield Functions. JARQ, 39, 121-134.

Furuya, J. et.al. (2015) Climate Change Effects on Long-term World-crop Production: Incorporating a Crop Model into Long-term Yield Estimates. JARQ, 49, 187-202.

International Monetary Fund (2017) World Economic Outlook Database. IMF.

Koizumi, T. \& Kanamaru, H. (2016) Contribution of Agricultural Investments to Stabilizing International Rice Price Volatility under Climate Change. JARQ, 50, 267-284.

Loblell, D.B. (2007) Changes in diurnal temperature range and national cereal yields. Agricultural and Forest Meteorology, 145, 229-238.

OECD-FAO (2017) OECD-FAO Agricultural Outlook 20172026. OECD-FAO.

OECD. General Service Support Estimates. https://stats.oecd. org/glossary/detail.asp?ID=1100.

United Nations (2017) World Population Prospects, the 2015 Revision. http://esa.un.org/unpd/wpp/.

United States Department of Agriculture, Foreign Agricultural Service (USDA-FAS 2017) PS\&D. USDA.

United States Department of Agriculture (USDA) (2017) Crop Calendars. USDA. 
Table A1-1. Estimation of parameters (yield)

\begin{tabular}{|c|c|c|c|c|c|c|c|c|}
\hline & France (EU) & $\begin{array}{l}\text { statistics (Year } \\
\text { for dummy) }\end{array}$ & Germany (EU) & $\begin{array}{l}\text { statistics (Year } \\
\text { for dummy) }\end{array}$ & Poland (EU) & $\begin{array}{l}\text { statistics (Year } \\
\text { for dummy) }\end{array}$ & China & t statistics \\
\hline a1, Average temperature of flowering season $(t / t-1)$ & -0.4343 & -1.5077 & -1.4726 & -4.3469 & 0.2223 & 1.8758 & 0.5286 & 1.9697 \\
\hline $\mathrm{a} 2$, Average precipitation of flowering season ( $\mathrm{t} / \mathrm{t}-1)$ & 0.3129 & 2.0237 & 0.0637 & 1.5764 & 0.0352 & 1.2879 & -0.0754 & -0.7544 \\
\hline $\begin{array}{l}\text { a3, Average amount of solar radiation of flowering } \\
\text { season }(t / t-1)\end{array}$ & 1.4029 & 1.7599 & 1.3150 & 3.3314 & 0.8123 & 1.8774 & -0.7433 & -1.4419 \\
\hline $\begin{array}{l}\text { a4, Agricultural Knowledge and Innovation System } \\
(\mathrm{t}-1 / \mathrm{t}-2)\end{array}$ & 0.5484 & 3.1528 & 0.1384 & 1.7861 & - & - & - & - \\
\hline $\begin{array}{l}\text { a5, Development and maintenance of inflastrucure } \\
(\mathrm{t}-1 / \mathrm{t}-2)\end{array}$ & & & 0.0479 & 1.5242 & 0.3376 & 2.9232 & - & - \\
\hline a6, Inspection and Control (t-1/t-2) & 0.0855 & 1.7621 & - & - & 0.2206 & 3.1010 & - & - \\
\hline a7, Land Development $(\mathrm{t}-1 / \mathrm{t}-2)$ & - & - & - & - & - & - & 1.6513 & 2.0603 \\
\hline a8, Agricultural machinery and equipment $(\mathrm{t}-1 / \mathrm{t}-2)$ & - & - & - & - & - & - & 0.1138 & 0.8048 \\
\hline Time trend $(t / t-1)$ & -0.0299 & -3.0187 & 0.0051 & 1.3966 & -0.0290 & -3.0998 & -0.0092 & -1.5536 \\
\hline Constant & 11.3424 & 109.7778 & 11.0244 & 84.1370 & 10.5611 & 102.0242 & 0.8610 & 24.8950 \\
\hline Dummy 1 & -0.1131 & $-2.1125(2003)$ & -0.1185 & $-2.4645(1989)$ & 0.2632 & $3.4369(2004)$ & - & - \\
\hline Dummy 2 & 0.1254 & $2.68823(2004)$ & 0.0833 & $1.8034(1991)$ & -0.2397 & $-3.5579(2006)$ & - & - \\
\hline Dummy 3 & - & - & - & - & - & - & - & - \\
\hline Sample & 1988-2009 & & 1989-2009 & & 1987-2009 & & 1980-2007 & \\
\hline R-squared & 0.8103 & & 0.9639 & & 0.8567 & & 0.8911 & \\
\hline Adjusted R-squared & 0.6681 & & 0.8969 & & 0.6848 & & 0.8600 & \\
\hline Durbin-Watson stat & 2.5418 & & 2.3893 & & 2.2120 & & 1.0276 & \\
\hline
\end{tabular}

Table A1-2. Estimation of parameters (yield)

\begin{tabular}{|c|c|c|c|c|c|c|c|c|}
\hline & India & $\begin{array}{l}\text { t statistics (Year } \\
\text { for dummy) }\end{array}$ & USA & $\begin{array}{l}t \text { statistics (Year } \\
\text { for dummy) }\end{array}$ & Russia & $\begin{array}{l}t \text { statistics (Year } \\
\text { for dummy) }\end{array}$ & Ukraine & $t$ statistics \\
\hline a1, Average temperature of flowering season $(t / t-1)$ & -0.5893 & -2.4254 & -0.3429 & -0.8776 & -1.8073 & -2.3514 & -0.6566 & -1.4107 \\
\hline $\mathrm{a} 2$, Average precipitation of flowering season $(\mathrm{t} / \mathrm{t}-1)$ & -0.0423 & -1.1394 & 0.1559 & 0.7014 & -0.1654 & -1.0726 & 0.9321 & 1.5934 \\
\hline $\begin{array}{l}\text { a3, Average amount of solar radiation of flowering } \\
\text { season }(t / t-1)\end{array}$ & 0.4962 & 1.6522 & 1.1075 & 1.8940 & 1.0910 & 1.2158 & 1.2205 & 0.7054 \\
\hline $\begin{array}{l}\text { a4, Agricultural Knowledge and Innovation System } \\
(\mathrm{t}-1 / \mathrm{t}-2)\end{array}$ & - & - & 0.2081 & 1.7935 & 0.4003 & 1.3750 & 0.4853 & 2.2011 \\
\hline $\begin{array}{l}\text { a5, Development and maintenance of infrastrucure } \\
(\mathrm{t}-1 / \mathrm{t}-2)\end{array}$ & - & - & 0.8492 & 1.2051 & 0.2260 & 3.2531 & 0.2930 & 2.1292 \\
\hline a6, Inspection and Control (t-1/t-2) & - & - & - & - & - & - & - & - \\
\hline a7, Land Development (t-1/t-2) & 0.8988 & 1.7776 & - & - & - & - & - & - \\
\hline a8, Agricultural machinery and equipment $(\mathrm{t}-1 / \mathrm{t}-2)$ & 0.1677 & 0.6695 & - & - & - & - & - & - \\
\hline Time trend $(\mathrm{t} / \mathrm{t}-1)$ & -0.0009 & -0.8526 & -0.0554 & -1.7622 & -0.0088 & -0.7495 & 0.1989 & 3.5366 \\
\hline Constant & 0.6380 & 8.3650 & 10.5324 & 45.3515 & 0.4234 & 1.4553 & -2.5890 & -2.6627 \\
\hline Dummy 1 & 0.1122 & $2.3613(1997)$ & -0.1712 & $-2.0667(2002)$ & -0.1786 & $-1.9858(2003)$ & - & - \\
\hline Dummy 2 & - & - & - & - & 0.1611 & $2.2772(2008)$ & - & - \\
\hline Dummy 3 & - & - & - & - & - & - & - & - \\
\hline Sample & 1984-2009 & & 1989-2009 & & 1995-2009 & & 2004-2014 & \\
\hline R-squared & 0.9177 & & 0.8088 & & 0.9851 & & 0.9210 & \\
\hline Adjusted R-squared & 0.8858 & & 0.6813 & & 0.9303 & & 0.7365 & \\
\hline Durbin-Watson stat & 1.3282 & & 1.6593 & & 2.1673 & & 2.1311 & \\
\hline
\end{tabular}

Table A1-3. Estimation of parameters (yield)

\begin{tabular}{|c|c|c|c|c|c|c|c|c|c|c|}
\hline & Canada & $\begin{array}{l}\text { t statistics (Year } \\
\text { for dummy) }\end{array}$ & Australia & t statistics & Argentina & $\begin{array}{l}\text { t statistics (Year } \\
\text { for dummy) }\end{array}$ & Egypt & t statistics & $\begin{array}{l}\text { Pakistan (The } \\
\text { rest of the world) }\end{array}$ & t statistics \\
\hline a1, Average temperature of flowering season $(t / t-1)$ & -0.5255 & -3.5878 & -0.9388 & -2.8071 & 0.8319 & 2.9602 & 0.3716 & 0.8958 & -0.5004 & -3.3184 \\
\hline a2, Average precipitation of flowering season $(\mathrm{t} / \mathrm{t}-1)$ & -0.9947 & -3.7729 & 0.7958 & 1.6348 & 0.2956 & 1.6727 & 0.4205 & 1.3738 & 0.0251 & 1.0764 \\
\hline $\begin{array}{l}\text { a3, Average amount of solar radiation of flowering } \\
\text { season }(t / t-1)\end{array}$ & - & - & 1.0524 & 1.1440 & 1.1461 & 0.9515 & 0.6350 & 0.9601 & 1.0496 & 1.4823 \\
\hline a4, Agricultural Machinery and Equipment (t-1/t-2) & 0.3005 & 0.9529 & 0.1905 & 1.5337 & - & - & - & - & - & - \\
\hline $\begin{array}{l}\text { a5, Development and maintenance of infrastrucure } \\
(\mathrm{t}-1 / \mathrm{t}-2)\end{array}$ & 0.3453 & 1.0864 & 0.1923 & 1.4126 & - & - & - & - & - & - \\
\hline a6, Inspection and Control (t-1/t-2) & - & - & - & - & - & - & - & - & - & - \\
\hline a7, Land Development (t-1/t-2) & - & - & - & - & - & - & - & - & 0.5944 & 0.8508 \\
\hline a8, Agricultural machinery and equipment $(\mathrm{t}-1 / \mathrm{t}-2)$ & - & - & - & - & 0.7382 & 1.2212 & 0.9478 & 2.0667 & 0.0353 & 1.5322 \\
\hline Time trend $(\mathrm{t} / \mathrm{t}-1)$ & 0.0269 & 1.8280 & -0.1022 & -1.5361 & - & - & - & - & 0.0183 & 3.0126 \\
\hline Constant & 5.0738 & 1.4393 & 0.9127 & 1.7718 & 8.1923 & 77.2851 & 1.1565 & 15.2572 & 0.3290 & 13.7801 \\
\hline Dummy 1 & -0.2320 & $-2.1384(1988)$ & - & - & -0.1720 & $-1.7638(1986)$ & - & - & - & - \\
\hline Dummy 2 & 0.2685 & $2.4779(1990)$ & - & - & 0.3077 & $2.4880(1989)$ & - & - & - & - \\
\hline Dummy 3 & - & - & - & - & -0.2751 & $-2.5256(1995)$ & - & - & - & - \\
\hline Sample & $1988-2009$ & & 1996-2009 & & 1982-2009 & & $1981-2009$ & & $1982-2009$ & \\
\hline R-squared & 0.9308 & & 0.9664 & & 0.8447 & & 0.8736 & & 0.9548 & \\
\hline Adjusted R-squared & 0.8361 & & 0.8542 & & 0.7005 & & 0.8314 & & 0.9419 & \\
\hline Durbin-Watson stat & 2.4808 & & 1.7741 & & 1.9030 & & 1.0626 & & 2.5532 & \\
\hline
\end{tabular}


Table A2-1. Estimation of parameters (planted area: 1)

\begin{tabular}{|c|c|c|c|c|c|c|c|c|}
\hline & France (EU) & $\begin{array}{c}\text { statistics (Year } \\
\text { for dummy) }\end{array}$ & Germany (EU) & t statistics & Poland (EU) & $\begin{array}{l}\text { statistics (Year } \\
\text { for dummy) }\end{array}$ & China & t statistics \\
\hline a9, Domestic wheat price $(t / t-1)$ & 0.4535 & 2.3960 & 0.5224 & 1.2644 & 0.3555 & 2.4943 & 0.1609 & 1.8613 \\
\hline a10, Average precipitation (t/t-1) & -0.0226 & -1.3084 & -0.0504 & -1.5976 & 0.2786 & 2.7987 & 0.1036 & 0.9831 \\
\hline a11, Domestic corn price $(t / t-1)$ & -0.1115 & -1.3937 & -0.0448 & -1.3087 & -0.3260 & -4.2094 & -0.0409 & -1.1838 \\
\hline a12, Domestic soybean price $(t / t-1)$ & - & - & - & - & - & - & - & - \\
\hline a13, Domestic coarse grain price $(t / t-1)$ & -0.4946 & -3.4540 & -0.3394 & -0.8505 & - & - & - & - \\
\hline a14, Domestic vegetable price $(t / t-1)$ & - & - & -0.0134 & -1.2646 & -0.1071 & -2.0530 & - & - \\
\hline a15, Domestic white sugar price $(t / t-1)$ & - & - & - & - & -0.1603 & -3.5538 & - & - \\
\hline a16, Domestic rice price $(t / t-1)$ & - & - & - & - & - & - & - & - \\
\hline $\begin{array}{l}\text { a17, Development and maintenance of infrastructure } \\
(\mathrm{t}-1 / \mathrm{t}-2)\end{array}$ & 0.1390 & 2.1854 & 0.1016 & 1.6306 & 0.3230 & 2.8405 & - & - \\
\hline a18, Domestic cotton price $(t / t-1)$ & - & - & - & - & - & - & -0.0248 & -1.7963 \\
\hline a19, Land development $(\mathrm{t}-1 / \mathrm{t}-2)$ & - & - & - & - & - & - & - & - \\
\hline Time trend $(\mathrm{t} / \mathrm{t}-1)$ & -0.0142 & -3.4809 & 0.0106 & 2.9305 & -0.0183 & -4.3856 & 0.0160 & 1.5346 \\
\hline Constant & 14.7489 & 34.572 & 13.8143 & 32.109 & 12.6882 & 16.2584 & 10.8119 & 263.4496 \\
\hline Dummy 1 & -0.1076 & $-4.374(1995)$ & - & - & -0.1835 & $-4.4989(1994)$ & - & - \\
\hline Dummy 2 & 0.0653 & $3.1232(2000)$ & - & - & 0.0251 & $0.0251(2009)$ & - & - \\
\hline Dummy 3 & -0.1025 & $-3.9195(2003)$ & - & - & - & - & - & - \\
\hline Sample & $1995-2010$ & & 1991-2009 & & $1992-2009$ & & 2002-2016 & \\
\hline R-squared & 0.9771 & & 0.9295 & & 0.9396 & & 0.9766 & \\
\hline Adjusted R-squared & 0.9140 & & 0.8731 & & 0.8533 & & 0.9532 & \\
\hline Durbin-Watson stat & 2.8643 & & 2.7402 & & 2.4796 & & 2.3269 & \\
\hline
\end{tabular}

Table A2-2. Estimation of parameters (planted area: 2)

\begin{tabular}{|c|c|c|c|c|c|c|c|c|}
\hline & India & $\begin{array}{l}t \text { statistics (Year } \\
\text { for dummy) }\end{array}$ & USA & t statistics & Russia & $\begin{array}{l}t \text { statistics (Year } \\
\text { for dummy) }\end{array}$ & Ukraine & $\begin{array}{l}t \text { statistics (Year } \\
\text { for dummy) }\end{array}$ \\
\hline a9, Domestic wheat price $(t / t-1)$ & 0.0890 & 0.7761 & 0.2730 & 2.8073 & 0.5972 & 3.5913 & 0.0812 & 1.8097 \\
\hline a10, Average precipitation $(t / t-1)$ & 0.0258 & 1.2861 & 0.0766 & 1.7960 & 0.2792 & 1.4002 & 1.2772 & 1.8881 \\
\hline a11, Domestic corn price $(t / t-1)$ & - & - & - & - & -0.1797 & -2.3895 & -0.9451 & -2.3515 \\
\hline a12, Domestic soybean price $(\mathrm{t} / \mathrm{t}-1)$ & - & - & - & - & - & - & - & - \\
\hline a13, Domestic coarse grain price $(t / t-1)$ & - & - & -0.0949 & -0.9848 & -0.1797 & -2.3895 & -0.1399 & -2.2216 \\
\hline a14, Domestic vegetable price $(\mathrm{t} / \mathrm{t}-1)$ & - & - & - & - & -0.0517 & -0.8078 & -0.2542 & -0.7470 \\
\hline a15, Domestic white sugar price $(t / t-1)$ & - & - & - & - & - & - & -0.9979 & -1.9197 \\
\hline a16, Domestic rice price $(t / t-1)$ & -0.0685 & -1.5290 & - & - & - & - & - & - \\
\hline $\begin{array}{l}\text { a17, Development and maintenance of infrastructure } \\
(\mathrm{t}-1 / \mathrm{t}-2)\end{array}$ & - & - & 0.0135 & 1.3526 & 0.0653 & 1.2677 & 0.5139 & 4.0651 \\
\hline a18, Domestic cotton price $(t / t-1)$ & - & - & - & - & - & - & - & - \\
\hline a19, Land development $(\mathrm{t}-1 / \mathrm{t}-2)$ & 0.8588 & 0.9740 & - & - & - & - & - & - \\
\hline Time trend $(t / t-1)$ & -0.0058 & -0.5019 & -0.0239 & -5.6067 & -0.0017 & -1.2830 & 0.0067 & 1.1433 \\
\hline Constant & 10.1339 & 120.618 & 10.4352 & 136.264 & 10.4505 & 81.4966 & 7.0019 & 12.199 \\
\hline Dummy 1 & 0.0556 & $2.4155(2010)$ & - & - & -0.1996 & $-4.5187(2003)$ & 1.3425 & $3.0757(2009)$ \\
\hline Dummy 2 & 0.0566 & $2.8485(2011)$ & - & - & 0.1202 & $3.2315(2007)$ & - & - \\
\hline Dummy 3 & -0.0766 & $-2.0379(2014)$ & - & - & 0.0253 & $1.5101(2014)$ & - & - \\
\hline Sample & 2004-2016 & & $1992-2010$ & & $2002-2014$ & & 2003-2014 & \\
\hline R-squared & 0.9066 & & 0.9332 & & 0.9895 & & 0.9839 & \\
\hline Adjusted R-squared & 0.7197 & & 0.8998 & & 0.9371 & & 0.8230 & \\
\hline Durbin-Watson stat & 2.2063 & & 1.6090 & & 2.2312 & & 2.2186 & \\
\hline
\end{tabular}

Table A2-3. Estimation of parameters (planted area: 3)

\begin{tabular}{|c|c|c|c|c|c|c|c|c|c|c|}
\hline & Canada & $\begin{array}{l}t \text { statistics } \\
\text { (Year for } \\
\text { dummy) }\end{array}$ & Australia & $\begin{array}{l}\text { t statistics } \\
\text { (Year for } \\
\text { dummy) }\end{array}$ & Argentina & $\begin{array}{l}t \text { statistics } \\
\text { (Year for } \\
\text { dummy) }\end{array}$ & Egypt & $\begin{array}{l}t \text { statistics } \\
\text { (Year for } \\
\text { dummy) }\end{array}$ & $\begin{array}{l}\text { Pakistan } \\
\text { (The rest of } \\
\text { the world) }\end{array}$ & $\begin{array}{l}t \text { statistics } \\
\text { (Year for } \\
\text { dummy) }\end{array}$ \\
\hline a9, Domestic wheat price $(t / t-1)$ & 0.2841 & 1.5091 & 0.3165 & 1.7315 & 0.2170 & 0.8199 & 0.2763 & 1.9154 & 0.1045 & 2.1066 \\
\hline a10, Average precipitation (t/t-1) & 0.1875 & 1.2278 & 0.3961 & 2.7866 & 0.0948 & 1.3613 & 0.1034 & 0.9456 & -0.0281 & -1.0221 \\
\hline a11, Domestic corn prices（t/t-1) & - & - & - & - & - & - & - & - & - & - \\
\hline a12, Domestic soybean price $(t / t-1)$ & - & - & - & - & -0.6401 & -1.4088 & - & - & - & - \\
\hline a13, Domestic coarse grain price $(t / t-1)$ & - & - & -0.2511 & -1.3346 & -0.2085 & -1.0986 & - & - & - & - \\
\hline a14, Domestic vegetable price $(\mathrm{t} / \mathrm{t}-1)$ & -0.1350 & -1.2537 & - & - & - & - & - & - & - & - \\
\hline a15, Domestic white sugar price $(t / t-1)$ & - & - & - & - & - & - & - & - & - & - \\
\hline a16, Domestic rice price $(\mathrm{t} / \mathrm{t}-1)$ & - & - & - & - & - & - & - & - & - & - \\
\hline $\begin{array}{l}\text { a17, Development and maintenance of infrastructure } \\
(\mathrm{t}-1 / \mathrm{t}-2)\end{array}$ & 0.0640 & 1.7063 & 0.0385 & 0.9520 & - & - & - & - & - & - \\
\hline a18, Domestic cotton price $(t / t-1)$ & - & - & - & - & - & - & - & - & 0.2204 & 1.3791 \\
\hline a19, Land development (t-1/t-2) & - & - & - & - & - & - & 0.4696 & 0.8886 & - & - \\
\hline Time trend $(\mathrm{t} / \mathrm{t}-1)$ & -0.0318 & -7.9997 & 0.2091 & 1.1895 & 1.6420 & 2.3818 & 0.0102 & 1.1665 & -0.2023 & -1.5911 \\
\hline Constant & 9.9310 & 106.165 & 8.6955 & 14.141 & 0.6420 & 2.3818 & 6.5739 & 72.582 & 9.4134 & 37.800 \\
\hline Dummy 1 & -0.1621 & $-2.6131(2002)$ & 0.1067 & $2.5694(2003)$ & -0.2416 & $-2.0984(1995)$ & -0.1193 & $-1.4756(2002)$ & 0.0409 & $2.5481(2007)$ \\
\hline Dummy 2 & - & - & -0.1051 & $-2.1938(2006)$ & 0.0962 & $0.8315(2001)$ & -0.2826 & $-3.1663(2005)$ & 0.0275 & $1.8376(2011)$ \\
\hline Dummy 3 & - & - & - & - & -0.1518 & $-1.0741(2003)$ & - & - & 0.0123 & $1.6084(2014)$ \\
\hline Sample & $1992-2010$ & & $1999-2010$ & & $1992-2010$ & & $2002-2016$ & & 2004-2014 & \\
\hline R-squared & 0.9131 & & 0.9158 & & 0.8527 & & 0.8988 & & 0.8832 & \\
\hline Adjusted R-squared & 0.8577 & & 0.7868 & & 0.6685 & & 0.8230 & & 0.6106 & \\
\hline Durbin-Watson stat & 2.3314 & & 2.1684 & & 1.9062 & & 1.9281 & & 1.9491 & \\
\hline
\end{tabular}


Table A3-1. Estimation of parameters (per capita consumption for food: 1)

\begin{tabular}{|c|c|c|c|c|c|c|c|c|}
\hline & EU & t statistics & China & t statistics & India & $\begin{array}{l}\text { t statistics } \\
\text { (Year for } \\
\text { dummy) }\end{array}$ & USA & $\begin{array}{l}\text { t statistics } \\
\text { (Year for } \\
\text { dummy) }\end{array}$ \\
\hline a20, Income: Per capita GDP growth rate (t/t-1) & 0.1142 & 0.9081 & 0.0520 & 2.0300 & 0.0575 & 1.3278 & 0.1962 & 1.5312 \\
\hline a21, Domestic wheat price $(t / t-1)$ & -0.1531 & -1.0499 & -0.0169 & -0.9322 & -0.1206 & -2.1239 & -0.0269 & -1.1386 \\
\hline a22, Domestic rice price $(t / t-1)$ & - & - & 0.0290 & 3.7580 & 0.0296 & 1.6767 & 0.0428 & 2.2423 \\
\hline Time trend $(\mathrm{t} / \mathrm{t}-1)$ & 0.0161 & 2.1857 & -0.0169 & -6.3946 & 0.0042 & 1.3408 & -0.0143 & -2.9829 \\
\hline Constant & 4.5267 & 74.3892 & 4.6451 & 161.6695 & 3.9528 & 27.0053 & 4.6805 & 140.2273 \\
\hline Dummy 1 & - & - & - & - & -0.0480 & $-1.054(2001)$ & -0.0797 & $-4.1034(1990)$ \\
\hline Dummy 2 & - & - & - & - & 0.1069 & $2.0858(2002)$ & -0.0728 & $-3.6823(1991)$ \\
\hline Dummy 3 & - & - & - & - & 0.0934 & 1.9998 (2013) & - & - \\
\hline Sample & $2002-2013$ & & $1991-2011$ & & $1998-2016$ & & $1990-2016$ & \\
\hline R-squared & 0.9689 & & 0.9858 & & 0.7470 & & 0.9172 & \\
\hline Adjusted R-squared & 0.9512 & & 0.9822 & & 0.5447 & & 0.8924 & \\
\hline Durbin-Watson stat & 2.1811 & & 1.3961 & & 2.3705 & & 1.1990 & \\
\hline
\end{tabular}

Table A3-2. Estimation of parameters (per capita consumption for food: 2)

\begin{tabular}{|c|c|c|c|c|c|c|c|c|}
\hline & Russia & $\begin{array}{c}\text { t statistics } \\
\text { (Year for } \\
\text { dummy) }\end{array}$ & Ukraine & $\begin{array}{c}\text { statistics } \\
\text { (Year for } \\
\text { dummy) }\end{array}$ & Canada & t statistics & Australia & $\begin{array}{c}\text { statistics } \\
\text { (Year for } \\
\text { dummy) }\end{array}$ \\
\hline a20, Income: Per capita GDP growth rate $(\mathrm{t} / \mathrm{t}-1)$ & -0.0155 & -1.2556 & 0.2013 & 4.4450 & 0.0520 & 2.0300 & 0.0903 & 4.9435 \\
\hline a21, Domestic wheat price $(t / t-1)$ & -0.0146 & -1.3778 & -0.1813 & -3.3056 & -0.0169 & -0.9322 & -0.0865 & -5.6410 \\
\hline a22, Domestic rice price $(t / t-1)$ & - & - & - & - & 0.0290 & 3.7580 & 0.1661 & 13.3077 \\
\hline Time trend $(\mathrm{t} / \mathrm{t}-1)$ & 0.0013 & 1.8168 & -0.0216 & -6.6982 & -0.0169 & -6.3946 & -0.0018 & -0.8864 \\
\hline Constant & 5.0659 & 325.5731 & 5.3978 & 169.9031 & 4.6451 & 161.6695 & 4.8438 & 152.1088 \\
\hline Dummy 1 & -0.0562 & $-2.7563(1994)$ & 0.1343 & 2.6991 (1995) & - & - & -0.0471 & $-6.7059(2010)$ \\
\hline Dummy 2 & -0.0771 & $-3.8896(1995)$ & - & - & - & - & - & - \\
\hline Dummy 3 & 0.0376 & 2.0572 (2004) & - & - & - & - & - & - \\
\hline Sample & $1992-2015$ & & $1985-2009$ & & 1991-2011 & & 2003-2014 & \\
\hline R-squared & 0.7452 & & 0.7839 & & 0.9857 & & 0.9866 & \\
\hline Adjusted R-squared & 0.6337 & & 0.7407 & & 0.9821 & & 0.9754 & \\
\hline Durbin-Watson stat & 2.3014 & & 1.1829 & & 1.3961 & & 2.3581 & \\
\hline
\end{tabular}

Table A3-3. Estimation of parameters (per capita consumption for food: 3 )

\begin{tabular}{|c|c|c|c|c|c|c|c|c|}
\hline & Argentina & $\begin{array}{c}\text { t statistics } \\
\text { (Year for } \\
\text { dummy) }\end{array}$ & Indonesia & t statistics & Egypt & $\begin{array}{c}\text { statistics } \\
\text { (Year for } \\
\text { dummy) }\end{array}$ & $\begin{array}{l}\text { Pakistan (The } \\
\text { rest of the } \\
\text { world) }\end{array}$ & $\begin{array}{c}\text { t statistics } \\
\text { (Year for } \\
\text { dummy) }\end{array}$ \\
\hline a20, Income: Per capita GDP growth rate $(\mathrm{t} / \mathrm{t}-1)$ & 0.1117 & 1.2534 & 0.3894 & 4.5173 & 0.0905 & 4.8811 & 0.1265 & 1.5533 \\
\hline a21, Domestic wheat price $(t / t-1)$ & -0.0608 & -1.3484 & -0.1877 & -2.1849 & -0.0541 & -2.4355 & -0.0300 & -1.6681 \\
\hline a22, Domestic rice price $(t / t-1)$ & - & - & 0.0536 & 1.1996 & - & - & 0.1265 & 1.5533 \\
\hline Time trend $(\mathrm{t} / \mathrm{t}-1)$ & 0.0034 & 1.4022 & 0.0021 & 1.3883 & 0.0007 & 0.9176 & -0.0148 & -5.3488 \\
\hline Constant & 4.8364 & 19.2548 & 2.6434 & 27.4364 & 5.0477 & 518.3757 & 5.2101 & 149.3880 \\
\hline Dummy 1 & 0.0487 & $2.1418(2007)$ & - & - & -0.0348 & $-4.1310(2002)$ & -0.0563 & $-1.4562(1990)$ \\
\hline Dummy 2 & 0.0487 & $2.2210(2009)$ & - & - & - & - & 0.0845 & $2.1579(1998)$ \\
\hline Dummy 3 & - & - & - & - & - & - & - & - \\
\hline Sample & 2005-2014 & & $1995-2016$ & & 2002-2016 & & $1990-2016$ & \\
\hline R-squared & 0.8593 & & 0.9289 & & 0.9371 & & 0.8507 & \\
\hline Adjusted R-squared & 0.6835 & & 0.9122 & & 0.9120 & & 0.8059 & \\
\hline Durbin-Watson stat & 2.1574 & & 1.2178 & & 2.1770 & & 1.0119 & \\
\hline
\end{tabular}


Table A4-1. Estimation of parameters (Consumption for feed: 1)

\begin{tabular}{|c|c|c|c|c|c|c|c|c|}
\hline & $\mathrm{EU}$ & t statistics & China & $\begin{array}{l}\text { statistics } \\
\text { (Year for } \\
\text { dummy) }\end{array}$ & India & t statistics & USA & $\begin{array}{l}\text { statistics } \\
\text { (Year for } \\
\text { dummy) }\end{array}$ \\
\hline a23, Income: GDP growth rate (t/t-1) & 0.1107 & 1.9480 & 0.4089 & 1.9495 & - & - & 2.7864 & 0.6395 \\
\hline a24, Domestic wheat price $(\mathrm{t} / \mathrm{t}-1)$ & -0.8535 & -9.0272 & -0.8833 & -2.0877 & - & - & -0.7196 & -1.4503 \\
\hline a25, Domestic beef price $(t / t-1)$ & 0.6776 & 4.9442 & - & - & - & - & 1.1048 & 1.9973 \\
\hline a26, Domestic pork price (t/t-1) & 0.7429 & 4.3202 & 1.8173 & 2.5514 & - & - & - & - \\
\hline a27, Domestic cheese price $(t / t-1)$ & - & - & - & - & - & - & - & - \\
\hline Time trend $(\mathrm{t} / \mathrm{t}-1)$ & -1.9970 & -6.3948 & 0.2263 & 0.2068 & - & - & -2.9037 & -1.8394 \\
\hline Constant & 22.3243 & 22.5150 & 7.1444 & 2.5838 & - & - & - & - \\
\hline Dummy 1 & -0.1063 & $-2.2728(2000)$ & 0.4981 & $1.5350(2001)$ & - & - & -2.3215 & $-5.6328(2007)$ \\
\hline Dummy 2 & 0.2513 & $4.3108(2007)$ & -0.6425 & $-2.0521(2005)$ & - & - & -0.6487 & $-1.8221(2010)$ \\
\hline Dummy 3 & - & - & -0.7988 & - & - & - & 0.8585 & - \\
\hline Sample & $2000-2013$ & & 1991-2016 & & - & & 1992-2015 & \\
\hline R-squared & 0.9921 & & 0.8739 & & - & & 0.8455 & \\
\hline Adjusted R-squared & 0.9743 & & 0.8145 & & - & & 0.7632 & \\
\hline Durbin-Watson stat & 2.2791 & & 1.6080 & & - & & 2.4977 & \\
\hline
\end{tabular}

Table A4-2. Estimation of parameters (Consumption for feed: 2)

\begin{tabular}{|c|c|c|c|c|c|c|c|c|c|c|}
\hline & Russia & tstatistics & Ukraine & $\begin{array}{l}\text { statistics } \\
\text { (Year for } \\
\text { dummy) }\end{array}$ & Canada & $\begin{array}{l}\text { statistics } \\
\text { (Year for } \\
\text { dummy) }\end{array}$ & Australia & $\begin{array}{l}\text { tstatistics } \\
\text { (Year for } \\
\text { dummy) }\end{array}$ & Egypt & $\begin{array}{l}\text { tstatistics } \\
\text { (Year for } \\
\text { dummy) }\end{array}$ \\
\hline a23, Income: GDP growth rate (t/t-1) & 0.3537 & 2.2448 & 2.0753 & 2.7036 & 1.0033 & 1.8421 & 0.9790 & 2.0232 & 0.3367 & 1.2055 \\
\hline a24, Domestic wheat price $(t / t-1)$ & -0.4776 & -2.5290 & -0.2675 & -1.1826 & -0.1745 & -1.6587 & -0.6887 & -2.4727 & -0.7608 & -1.7769 \\
\hline a25, Domestic beef price $(t / t-1)$ & 1.1609 & 3.2602 & - & - & - & - & 0.9390 & 1.5969 & - & - \\
\hline a26, Domestic pork price $(t / t-1)$ & - & - & - & - & - & - & - & - & - & - \\
\hline a27, Domestic cheese price $(t / t-1)$ & 0.2519 & 1.9821 & - & - & - & - & - & - & 0.5264 & 1.8784 \\
\hline Time trend $(t / t-1)$ & -1.2558 & -5.4487 & -3.3132 & -4.2001 & -1.2909 & -2.0897 & -2.2728 & -1.2699 & 0.2854 & 1.6924 \\
\hline Constant & 12.1926 & 25.7531 & 14.7687 & 10.7618 & 11.4889 & 8.1082 & 15.3470 & 2.8555 & 5.5207 & 5.4662 \\
\hline Dummy 1 & 0.4959 & $4.2396(2007)$ & -0.7341 & $-1.5916(1999)$ & -0.4024 & $-2.1384(1992)$ & 0.1209 & $1.7283(2007)$ & -1.9164 & $-6.0759(1994)$ \\
\hline Dummy 2 & 0.1140 & $1.2046(2013)$ & -1.2240 & $-2.2687(2003)$ & -0.6398 & $-4.0925(2007)$ & -0.6455 & $-5.1718(2009)$ & -0.7756 & $-2.2465(2001)$ \\
\hline Dummy 3 & 0.3696 & $3.5413(2014)$ & 0.7432 & - & -0.3581 & $-2.3038(2009)$ & - & - & 0.4981 & $1.5909(2009)$ \\
\hline Sample & 1999-2016 & & $1997-2015$ & & $1992-2015$ & & $2000-2014$ & & $1990-2014$ & \\
\hline R-squared & 0.9102 & & 0.8265 & & 0.8033 & & 0.8998 & & 0.8952 & \\
\hline Adjusted R-squared & 0.8093 & & 0.6877 & & 0.6768 & & 0.7662 & & 0.8428 & \\
\hline Durbin-Watson stat & 1.9972 & & 2.3428 & & 2.3056 & & 1.4615 & & 1.8162 & \\
\hline
\end{tabular}


Table A5-1. Estimation of parameters (imports: 1)

\begin{tabular}{lcccccc}
\hline \hline & EU & $\begin{array}{c}\text { t statistics (Year } \\
\text { for dummy) }\end{array}$ & USA & $\begin{array}{c}\text { t statistics (Year } \\
\text { for dummy) }\end{array}$ & $\begin{array}{c}\text { Russia } \\
\text { fstatistics (Year } \\
\text { for dummy) }\end{array}$ \\
\hline a28, Domestic Wheat price (t/t-1) & -0.8403 & -3.5474 & -1.2500 & -2.2243 & -1.1069 & -1.3708 \\
Time trend (t/t-1) & -0.0192 & -1.5397 & 0.0288 & 3.8076 & -0.1056 & -4.3493 \\
Constant & 9.2279 & 25.0941 & 7.7408 & 43.0037 & 10.3374 & 15.7495 \\
Dummy 1 & -0.3522 & $-2.7290(2006)$ & -0.6948 & $-4.2185(1991)$ & -1.4890 & $-2.2988(2009)$ \\
Dummy 2 & -0.3440 & $-2.5766(2009)$ & -0.4392 & $-2.7890(2003)$ & -1.9222 & $-2.9481(2010)$ \\
Dummy 3 & -0.4615 & $-3.3879(2013)$ & -0.3731 & $-2.3625(2004)$ & - & - \\
Sample & $2001-2015$ & & $1991-2015$ & & $1992-2015$ & \\
R-squared & 0.8645 & & 0.8151 & & 0.7879 & 0.7289 \\
Adjusted R-squared & 0.7628 & & 0.7535 & & & \\
Durbin-Watson stat & 2.4207 & & 2.3426 & & & 1.4662 \\
\hline
\end{tabular}

Table A5-2. Estimation of parameters (imports: 2)

\begin{tabular}{lcccccc}
\hline \hline & Ukraine & $\begin{array}{c}\text { t statistics (Year } \\
\text { for dummy) }\end{array}$ & Canada & $\begin{array}{c}\text { t statistics (Year } \\
\text { for dummy) }\end{array}$ & $\begin{array}{c}\text { Australia } \\
\text { statistics (Year } \\
\text { for dummy) }\end{array}$ \\
\hline a28, Domestic Wheat price (t/t-1) & -0.8916 & -1.6209 & -0.4858 & -3.0643 & -0.2555 & -1.0443 \\
Time trend (t/t-1) & -0.2492 & -5.3424 & 0.0701 & 6.9087 & 0.0689 & 13.4260 \\
Constant & 11.7415 & 8.1381 & 3.6394 & 15.4778 & 2.8436 & 21.1297 \\
Dummy 1 & -0.9566 & $-2.083(2012)$ & 0.3507 & $2.4872(2002)$ & -0.5176 & $-3.8954(1991)$ \\
Dummy 2 & - & - & - & - & -0.3509 & $-2.8459(1993)$ \\
Dummy 3 & - & - & - & - & 1.3533 & $11.8081(2002)$ \\
Sample & $2005-2016$ & & $1997-2015$ & & $1991-2015$ & \\
R-squared & 0.8379 & & 0.9259 & & 0.9760 & \\
Adjusted R-squared & 0.7299 & & 0.9048 & & 0.9680 & \\
Durbin-Watson stat & 2.4045 & & 2.2119 & & & 1.7413 \\
\hline
\end{tabular}

Table A6. Estimation of parameters (exports)

\begin{tabular}{|c|c|c|c|c|c|c|c|c|c|c|}
\hline & China & $\begin{array}{l}t \text { statistics (Year } \\
\text { for dummy) }\end{array}$ & Egypt & $\begin{array}{c}\text { tstatistics (Year } \\
\text { for dummy) }\end{array}$ & India & $\begin{array}{c}\text { tstatistics (Year } \\
\text { for dummy) }\end{array}$ & Indonesia & $\begin{array}{c}\text { tstatistics (Year } \\
\text { for dummy) }\end{array}$ & $\begin{array}{l}\text { Pakistan (The } \\
\text { rest of the world) }\end{array}$ & $\begin{array}{c}\text { tstatistics (Year } \\
\text { for dummy) }\end{array}$ \\
\hline a29, International Wheat price $(t / t-1)$ & 0.1815 & 2.6479 & 0.5092 & 1.0524 & 0.8186 & 3.4879 & 0.2864 & 1.2347 & 1.0536 & 3.0826 \\
\hline Time trend $(t / t-1)$ & -0.0136 & -1.8240 & 0.2877 & 8.5621 & 0.4036 & 4.0658 & 0.0894 & 5.6270 & -0.0448 & -1.8952 \\
\hline Constant & 7.2175 & 28.7044 & -4.2554 & -4.3216 & -7.8610 & -2.4230 & - & - & 7.9818 & 11.3777 \\
\hline Dummy 1 & -0.1484 & $-3.0902(2014)$ & -0.1014 & $-2.008(2006)$ & 5.5029 & $3.8763(2005)$ & -0.5184 & $-1.9603(2001)$ & -0.9384 & $-2.4178(2000)$ \\
\hline Dummy 2 & -0.1139 & $-2.4374(2015)$ & - & - & -3.2863 & $-2.8031(2008)$ & 0.7401 & $2.9769(2004)$ & -1.3560 & $-3.7687(2003)$ \\
\hline Dummy 3 & - & - & - & - & - & - & - & - & -1.0336 & $-3.0366(2009)$ \\
\hline Sample & 2009-2016 & & 2001-2016 & & $2005-2016$ & & $2000-2016$ & & $2000-2016$ & \\
\hline R-squared & 0.9403 & & 0.9257 & & 0.8416 & & 0.8930 & & 0.8496 & \\
\hline Adjusted R-squared & 0.8607 & & 0.9071 & & 0.7511 & & 0.8574 & & 0.7595 & \\
\hline Durbin-Watson stat & 2.2390 & & 1.8388 & & 2.0346 & & 1.3802 & & 1.8367 & \\
\hline
\end{tabular}


Table A7-1. Estimation of parameters (ending stocks: 1)

\begin{tabular}{|c|c|c|c|c|c|c|c|c|}
\hline & EU & $\begin{array}{l}\text { t statistics (Year } \\
\text { for dummy) }\end{array}$ & China & $\begin{array}{l}\text { t statistics (Year } \\
\text { for dummy) }\end{array}$ & India & $\begin{array}{l}\text { t statistics (Year } \\
\text { for dummy) }\end{array}$ & USA & $\begin{array}{l}\text { t statistics (Year } \\
\text { for dummy) }\end{array}$ \\
\hline a30, Domestic wheat price $(\mathrm{t} / \mathrm{t}-1)$ & -0.2213 & -1.8303 & -0.3644 & -2.6186 & -0.6226 & -2.4817 & -0.4334 & -1.6566 \\
\hline Time trend $(\mathrm{t} / \mathrm{t}-1)$ & -0.0522 & -3.0770 & -0.0186 & -3.1924 & -0.0652 & -1.4114 & 0.0467 & 5.7403 \\
\hline Constant & 10.8359 & 28.1024 & 8.3819 & 24.5851 & 4.0352 & 4.8340 & 8.9154 & 45.3646 \\
\hline Dummy 1 & 0.3783 & $2.6869(1986)$ & -0.9125 & $-4.1271(2011)$ & 0.7543 & $1.6988(2001)$ & -0.4731 & $-2.8181(2003)$ \\
\hline Dummy 2 & -0.2797 & $-1.9598(1994)$ & -1.1142 & $-4.8007(2012)$ & -0.9937 & $-2.2356(1997)$ & -0.4007 & $-2.4524(2004)$ \\
\hline Dummy 3 & - & - & - & - & -0.9187 & $-2.0923(2004)$ & -0.5965 & $-3.3111(2007)$ \\
\hline Sample & $1980-1996$ & & $1989-2015$ & & $1991-2008$ & & 1991-2015 & \\
\hline $\mathrm{R}$-squared & 0.8646 & & 0.7727 & & 0.8236 & & 0.8251 & \\
\hline Adjusted R-squared & 0.7834 & & 0.7186 & & 0.7000 & & 0.7531 & \\
\hline Durbin-Watson stat & 2.2368 & & 1.3558 & & 1.6161 & & 1.2648 & \\
\hline
\end{tabular}

Table A7-2. Estimation of parameters (ending stocks: 2)

\begin{tabular}{|c|c|c|c|c|c|c|c|c|}
\hline & Russia & $\begin{array}{l}t \text { statistics (Year } \\
\text { for dummy) }\end{array}$ & Ukraine & $\begin{array}{l}t \text { statistics (Year } \\
\text { for dummy) }\end{array}$ & Canada & $\begin{array}{l}\text { t statistics (Year } \\
\text { for dummy) }\end{array}$ & Australia & $\begin{array}{l}\text { t statistics (Year } \\
\text { for dummy) }\end{array}$ \\
\hline a30, Domestic wheat price $(\mathrm{t} / \mathrm{t}-1)$ & -0.5447 & -1.7878 & -0.6924 & -2.0054 & -0.4743 & -2.3833 & -0.6829 & -3.5677 \\
\hline Time trend $(\mathrm{t} / \mathrm{t}-1)$ & -0.0473 & -1.6333 & 0.0406 & 1.2333 & 0.0061 & 0.6580 & 0.0645 & 6.7236 \\
\hline Constant & 8.0226 & 7.8994 & 7.4437 & 11.6727 & 8.6816 & 43.4430 & 7.2759 & 33.5099 \\
\hline Dummy 1 & 0.7721 & $1.5426(1996)$ & -0.6979 & $-3.3067(1999)$ & -0.4193 & $-2.5806(1994)$ & 0.7534 & $0.7534(1992)$ \\
\hline Dummy 2 & 1.4365 & $2.8403(2003)$ & 0.4240 & $1.9679(2007)$ & -0.2528 & $-1.7591(1997)$ & -0.5786 & $-2.8058(1998)$ \\
\hline Dummy 3 & - & - & - & - & 0.2306 & 1.3407 (2013) & - & - \\
\hline Sample & $1987-2008$ & & 1994-2008 & & $1991-2014$ & & $1991-2015$ & \\
\hline R-squared & 0.7314 & & 0.8885 & & 0.8069 & & 0.8441 & \\
\hline Adjusted R-squared & 0.6240 & & 0.8049 & & 0.7224 & & 0.7922 & \\
\hline Durbin-Watson stat & 1.8014 & & 1.5693 & & 2.0506 & & 1.4829 & \\
\hline
\end{tabular}

Table A7-3. Estimation of parameters (ending stocks: 3)

\begin{tabular}{|c|c|c|c|c|c|c|c|c|}
\hline & Argentina & t statistics & Indonesia & t statistics & Egypt & $\begin{array}{l}t \text { statistics (Year } \\
\text { for dummy) }\end{array}$ & Pakistan & $\begin{array}{l}t \text { statistics (Year } \\
\text { for dummy) }\end{array}$ \\
\hline a30, Domestic wheat price $(\mathrm{t} / \mathrm{t}-1)$ & - & - & - & - & -0.5450 & -1.7067 & -0.1392 & -1.0657 \\
\hline Time trend $(\mathrm{t} / \mathrm{t}-1)$ & 0.1003 & 5.2195 & -0.0107 & -0.2221 & -0.0979 & -1.5834 & -0.0338 & -1.8153 \\
\hline Constant & 4.4068 & 7.3772 & 6.2108 & 11.4649 & 5.0763 & 15.8461 & 7.6397 & 39.1824 \\
\hline Dummy 1 & - & - & - & - & 0.7367 & $2.2879(1996)$ & -0.6486 & $-3.9178(2002)$ \\
\hline Dummy 2 & - & - & - & - & 0.7697 & 2.5314 (1997) & -0.5556 & $-3.4955(2003)$ \\
\hline Dummy 3 & - & - & - & - & - & - & -0.3237 & $-2.0186(2013)$ \\
\hline Sample & $1995-2014$ & & $1998-2015$ & & $1991-2014$ & & $1995-2015$ & \\
\hline R-squared & 0.7865 & & 0.7433 & & 0.9051 & & 0.8027 & \\
\hline Adjusted R-squared & 0.6879 & & 0.6893 & & 0.8716 & & 0.7181 & \\
\hline Durbin-Watson stat & 1.0662 & & 1.3219 & & 1.5201 & & 1.8761 & \\
\hline
\end{tabular}


Table A8-1. Estimation of parameters (price tranmission: 1)

\begin{tabular}{|c|c|c|c|c|c|c|c|c|c|c|}
\hline & EU & $\begin{array}{l}\text { tstatistics (Year } \\
\text { for dummy) }\end{array}$ & China & t statistics & India & $\begin{array}{c}\text { statistics (Year } \\
\text { for dummy) }\end{array}$ & USA & t statistics & Russia & $\begin{array}{l}\text { t statistics (Year } \\
\text { for dummy) }\end{array}$ \\
\hline a31, International wheat price $(t / t-1)$ & 0.9662 & 9.3967 & 0.6310 & 7.5389 & 0.3449 & 5.9326 & 0.9309 & 20.2469 & 0.9909 & 7.3505 \\
\hline Time trend $(t / t-1)$ & -0.0057 & -1.1874 & 0.0388 & 9.5702 & 0.0243 & 7.3530 & 0.0090 & 4.3838 & 0.0069 & 1.0382 \\
\hline Constant & 4.8969 & 83.6228 & 4.6764 & 104.7225 & 4.8082 & 139.0873 & 4.6807 & 192.9311 & 4.5578 & 53.4204 \\
\hline Dummy 1 & 0.3936 & $2.8553(1991)$ & -0.3102 & -3.0702 & 0.3024 & 4.2741 (1991) & - & - & 0.8642 & $4.7718(1992)$ \\
\hline Dummy 2 & -0.3355 & $-2.5593(2002)$ & - & - & -0.1736 & $-2.6409(2002)$ & - & - & -0.4780 & $-2.8346(2002)$ \\
\hline Dummy 3 & 0.3255 & $2.4669(2010)$ & - & - & -0.1230 & $-1.8539(2003)$ & - & - & - & - \\
\hline Sample & $1991-2015$ & & 1991-2011 & & 1991-2008 & & $1991-2015$ & & $1992-2015$ & \\
\hline R-squared & 0.8915 & & 0.9477 & & 0.9181 & & 0.9759 & & 0.8850 & \\
\hline Adjusted R-squared & 0.8629 & & 0.9385 & & 0.8839 & & 0.9738 & & 0.8607 & \\
\hline Durbin-Watson stat & 1.8065 & & 1.5415 & & 2.2546 & & 2.0201 & & 2.3919 & \\
\hline
\end{tabular}

Table A8-2. Estimation of parameters (price tranmission: 2)

\begin{tabular}{|c|c|c|c|c|c|c|c|c|c|c|c|c|}
\hline & Ukraine & $\begin{array}{l}\text { t statistics } \\
\text { (Year for } \\
\text { dummy) }\end{array}$ & Canada & $\begin{array}{l}\text { t statistics } \\
\text { (Year for } \\
\text { dummy) }\end{array}$ & Australia & $\begin{array}{l}t \text { statistics } \\
\text { (Year for } \\
\text { dummy) }\end{array}$ & Argentina & $\begin{array}{c}\text { tstatistics } \\
\text { (Year for } \\
\text { dummy) }\end{array}$ & Egypt & $\begin{array}{l}\text { t statistics } \\
\text { (Year for } \\
\text { dummy) }\end{array}$ & $\begin{array}{l}\text { Pakistan } \\
\text { (The rest of } \\
\text { the world) }\end{array}$ & $\begin{array}{l}\text { tstatistics } \\
\text { (Year for } \\
\text { dummy) }\end{array}$ \\
\hline $\begin{array}{l}\text { a31, International } \\
\text { wheat price }(t / t-1)\end{array}$ & 0.5342 & 4.0981 & 0.5807 & 5.0375 & 0.7067 & 8.3293 & 0.7465 & 8.2500 & 0.4068 & 3.1281 & 0.1937 & 1.4990 \\
\hline Time trend $(t / t-1)$ & 0.0235 & 3.3704 & 0.0348 & 6.5393 & 0.0151 & 3.7569 & -0.0071 & -1.4508 & 0.0299 & 5.2601 & 0.0206 & 3.9598 \\
\hline Constant & 4.3372 & 52.8961 & 4.2694 & 66.7674 & 4.7845 & 105.8621 & 4.8893 & 85.0569 & 4.9358 & 77.8535 & 4.8971 & 87.8836 \\
\hline Dummy 1 & 0.4235 & $2.5832(1994)$ & -0.2981 & $-1.9621(1994)$ & -0.1879 & $-1.7576(2006)$ & -0.4013 & $-3.3472(1992)$ & -0.4665 & $-3.0765(1992)$ & 0.3354 & $2.5822(2009)$ \\
\hline Dummy 2 & -0.3733 & $-2.3219(1999)$ & -0.3052 & $-2.0846(2006)$ & - & - & 0.6152 & 5.2689 (2013) & -0.3534 & $-2.3101(1996)$ & -0.2414 & $-1.9195(2001)$ \\
\hline Dummy 3 & -0.4176 & $-2.7460(2002)$ & - & - & - & - & -0.2629 & $-2.3853(2006)$ & 0.3526 & 0.3526 (1997) & -0.3363 & $-2.2700(2008)$ \\
\hline Sample & $1994-2015$ & & $1991-2015$ & & 1991-2014 & & $1992-2014$ & & $1980-2003$ & & $1991-2010$ & \\
\hline R-squared & 0.8865 & & 0.9122 & & 0.9144 & & 0.9141 & & 0.8847 & & 0.7907 & \\
\hline Adjusted R-squared & 0.8511 & & 0.8946 & & 0.9015 & & 0.8885 & & 0.8526 & & 0.7160 & \\
\hline Durbin-Watson stat & 2.2123 & & 1.3617 & & 1.8517 & & 1.3054 & & 1.0075 & & 1.1549 & \\
\hline
\end{tabular}

Table A9-1. Exogenous variables (1)

\begin{tabular}{lcrr}
\hline \hline & Per Capita GDP & \multicolumn{2}{c}{ Population } \\
\hline Countries/Region & Changing rate $(2017-2022)(\%)$ & $2014-2016$ & 5040 \\
\hline EU28 & 1.8 & 507,519 & 509,687 \\
China & 7.5 & $1,396,880$ & $1,417,473$ \\
India & 9.1 & $1,309,028$ & $1,605,356$ \\
USA & 3.8 & 319,943 & 374,069 \\
Russia & 2.8 & 143,871 & 135,837 \\
Ukraine & 6.3 & 44,660 & 38,658 \\
Canada & 1.4 & 35,948 & 43,005 \\
Australia & 2.8 & 23,800 & 30,765 \\
Argentina & 6.4 & 43,416 & 52,586 \\
Indonesia & 8.7 & 258,136 & 312,134 \\
Egypt & 5.6 & 93,760 & 137,066 \\
\hline
\end{tabular}

Table A9-2. Exogenous variables (2)

\begin{tabular}{|c|c|c|c|c|}
\hline & Unit & $2014-2016$ & 2026 & 2040 \\
\hline International corn price & USD/ton & 164 & 197 & 197 \\
\hline International coarse grain price & USD/ton & 179 & 198 & 198 \\
\hline International rice price & USD/ton & 375 & 416 & 416 \\
\hline International soybean price & USD/ton & 402 & 446 & 446 \\
\hline International vegetable oil price & USD/ton & 768 & 902 & 902 \\
\hline International cotton price & USD/ton & 1,583 & 1,576 & 1,576 \\
\hline International white sugar price & USD/ton & 430 & 453 & 453 \\
\hline International beef price & USD/ton & 4,298 & 3,894 & 3,894 \\
\hline International pork price & USD/ton & 2,122 & 2,396 & 2,396 \\
\hline International cheese price & USD/ton & 3,633 & 4,276 & 4,276 \\
\hline
\end{tabular}

